\title{
USING LAND COVER CHANGES AND DEMOGRAPHIC DATA TO IMPROVE HYDROLOGICAL MODELLING IN THE SAHEL
}

\begin{tabular}{|r|l|}
\hline Journal: & Hydrological Processes \\
\hline Manuscript ID & HYP-15-0194.R2 \\
\hline Wiley - Manuscript type: & Research Article \\
\hline Date Submitted by the Author: & n/a \\
\hline Complete List of Authors: & $\begin{array}{l}\text { Paturel, Jean-Emmanuel; IRD, HSM; IRD, } \\
\text { Mahe, Gil; IRD, HSM } \\
\text { Diello, Pierre; IRD, HSM } \\
\text { Barbier, Bruno; CIRAD, G-EAU } \\
\text { Dezetter, Alain; IRD, HydroSciences Montpellier } \\
\text { Dieulin, Claudine; IRD, HSM } \\
\text { KARAMBIRI, Harouna; nstitut International d'Ingénierie de I'Eau et de } \\
\text { l'Environnement, Laboratoire Hydrologie et Ressources en Eau } \\
\text { YACOUBA, Hamma; Institut International d'Ingénierie de I'Eau et de } \\
\text { I'Environnement, Laboratoire Hydrologie et Ressources en Eau } \\
\text { Maiga, Amadou; Institut International d'Ingénierie de I'Eau et de } \\
\text { I'Environnement, Laboratoire Hydrologie et Ressources en Eau }\end{array}$ \\
\hline Keywords: & $\begin{array}{l}\text { Sahel, land-cover, demographic model, environmental indicators, } \\
\text { Hydrological modelling }\end{array}$ \\
\hline & \\
\hline
\end{tabular}




\title{
USING LAND COVER CHANGES AND DEMOGRAPHIC DATA TO IMPROVE
}

\author{
HYDROLOGICAL MODELLING IN THE SAHEL
}

\author{
Jean Emmanuel PATUREL ${ }^{\mathrm{a}}$, Gil MAHÉ ${ }^{\mathrm{a}}$, Pierre DIELLO ${ }^{\mathrm{a}}$, Bruno BARBIER ${ }^{\mathrm{b}}$, Alain \\ DEZETTER $^{\mathrm{a}}$, Claudine DIEULIN ${ }^{\mathrm{a}}$, Harouna KARAMBIRI ${ }^{\mathrm{b}}$, Hamma YACOUBA $^{\mathrm{b}}$, Amadou \\ MAIGA $^{\mathrm{b}}$ \\ a IRD - HydroSciences Montpellier Université Montpellier 2 - CC MSE - Place Eugène \\ Bataillon - 34095 Montpellier Cedex 5 - France. \\ b 2IE. Rue de la Science - 01 BP 594 - Ouagadougou 01 - Burkina Faso. \\ * Corresponding author: jean-emmanuel.paturel@ird.fr
}

Summary At the beginning of the drought in the Sahel in the 1970s and 1980s, rainfall decreased markedly, but runoff coefficients and in some cases absolute runoff increased. This situation was due to the conversion of the land cover from natural vegetation with a low annual runoff coefficient, to cropland and bare soils, whose runoff coefficients are higher. Unless they are adapted, hydrological conceptual models such as GR2M, are unable to reproduce this increase in runoff.

Despite the varying environmental and climatic conditions of the West African Sahel, we show that it is possible to increase the performance of the GR2M model simulations by elaborating a time-varying soil water holding capacity (WHC), and to incorporate this value in the annual maximum amount of water to be stored in reservoir A of the model.

We looked for interactions between climate, rural society and the environment. These interactions drive land-cover changes in the Sahel, which in turn drive the distribution of rainfall between infiltration, evaporation and runoff, and hence the water resources, which are vital in this region. We elaborated several time series of key indicators linked to these interactions.

We then integrated these changes in the runoff conditions of the GR2M model through the maximum value of the reservoir capacity. We calculated annual values of WHC using the annual values of four classes of land cover, natural vegetation, cultivated area, bare soil and surface water. We then used the hydrological model with and without this time-varying soil value of $\mathrm{A}$, and compared the performances of the model under the two scenarios.

Whatever the calibration period used, the Nash-Sutcliffe index was always greater in the case of the time-varying A time series.

Keywords Hydrological modelling, Sahel, land cover, demographic model, soil water holding capacity, environmental indicators

\section{INTRODUCTION}

Rainfall patterns have changed markedly since the early 1970s. In West Africa, rainfall has decreased significantly (Servat et al., 1998) and near surface temperatures, especially low temperatures, have increased over the last 50 years (IPCC, 2013). This in turn has had an impact on the hydrology of most rivers (Mahé et al., 2013): in humid tropical West Africa, river discharges decreased significantly as a result of a drop in the groundwater level over two decades (1970-1990). In contrast, in the Sahel, the annual river runoff coefficients increased, despite the decrease in rainfall (Mahé \& Paturel, 2009), in some places leading to an absolute 
increase in runoff. This increase was correlated with the degradation of the land cover, which increased its imperviousness. While several hydrological models have been applied to West African rivers (Paturel et al., 2003; 2007; Ardoin-Bardin et al., 2009), little attention has been paid to large Sahelian rivers, partly because of the lack of data. Small basins have been the subject of more studies of the processes involved (for instance, Albergel et al., 1986;

Casenave \& Valentin, 1991). This paper investigates the dynamic relationship between land cover and surface runoff and how it can be modelled in the Sahel.

Following the study by Duley (1939), several authors highlighted the role played by the physical characteristics of the uppermost centimetres of the soil. After 1980, simulated rainfalls were used throughout the Sudano-Sahelian zone (Burkina Faso, Cameroon, Mali, Niger, Senegal and Togo) to rank natural environmental factors in terms of their impact on surface hydrodynamics (fig. 1). Casenave \& Valentin (1991) defined "surface features" as any elementary surface, any association of elementary surfaces, any juxtaposition of elementary surfaces and any interdependent system of elementary surfaces, elementary surface being defined as any homogeneous set made up at a given time, of the tree cover, soil type and soil surface organisations that have been subject to meteorological, animal or human influences.

Subsequent studies have confirmed the role of surface features in the variation in flows in the Sahel (Dolman et al., 1997; Nicholson, 2000; Legesse et al., 2003; Séguis et al., 2003).

The hydrological variability of Sahel hydrosystems is therefore directly linked to that of the surface features. However, in the past five decades, the Sahel has undergone major climatic and environmental changes, especially of surface features, leading to paradoxical observations:

- Studies conducted in the Nakanbé basin (Mahé et al., 2002, 2005a; Diello et al., 2006) and on the right bank of the Niger River (Mahé et al., 2003; Mahé \& Paturel, 2009; Descroix et al., 2009; Descroix et al., 2012; Sighomnou et al., 2013) have shown that despite a marked decrease in regional rainfall (\# 20\%) since 1970, runoff coefficients have increased drastically (up to $100 \%$ in the Nakanbé basin and at least $200 \%$ in the tributaries of the Niger river under Sahelian latitudes), sometimes resulting in higher discharges than previously, and leading to severe floods.

- After the 1970s, runoff increased in some basins in Mauritania, Burkina Faso and Niger (Mahé et al. 2005b; Mahé \& Paturel, 2009), along the whole Sahelian strip accounting for several hundreds of thousands $\mathrm{km}^{2}$. Changes in the hydrological regimes associated with these changes in rainfall-runoff relationships affect the hydrology of very large basins, such as the Niger River basin in Niamey. Its regime has significantly changed since the 1980s, with a "local / Sahel" flood in August-September, often greater than the "Fouta Djalon" flood, even as it comes from a much larger basin (Mahé et al., 2003; Sighomnou et al., 2013).

- Studies conducted in the Malian Gourma Sahelian region (Gardelle et al., 2010) have shown that the size of ponds has increased since the late 1980s.

In the first two cases, the authors highlighted the increase in human activities in recent decades. Under population pressure and in response to climatic change, these populations have increased cultivated areas at the expense of the natural vegetation. Land clearing resulted in a change in surface features which became more favourable to runoff.

In the third case, sparsely cultivated environments are subjected to intensive grazing pressure. Gardelle et al., (2010) argued that the decrease in rainfall and the death of vegetation during the 1970s and 1980s increased soil erosion and killed the tree cover because it could not naturally recover. In terms of water resources, it led to increased runoff in the most flowing part of the basin (Hiernaux and Le Houérou, 2006). 
It is likely that the combination of land clearing and the disappearance of the tree cover led to an overall increase in runoff coefficients. The first is caused by humans, while the second may be equally due to climate change, even if the importance of the high grazing pressure should not be underestimated, but is more difficult to quantify.

Along with these observations, the impact of the effects of these changes from a hydrological modelling perspective is questionable. In a study on 17 river basins in West and Central Africa, Lubès-Niel et al. (2003) showed that there is no link between parameter stability and the stationary behaviour of rainfall or runoff series of some catchments. But, with the same parameters, a hydrological model cannot reproduce an increase in runoff when there is a decrease in rainfall, which has been the case in the Sahel. The parameter sets would have to significantly change before and after 1969-1970. It is thus interesting to analyze how a rainfall-runoff model behaves before and after 1970, and especially its calibrated parameters sets.

Recent studies conducted on the apparent re-greening of the Sahel have pointed to the role of population pressure on changes in tree cover in the Sahel (Spiekermann et al., 2013) and more globally on Sahelian vegetation dynamics (Seaquist et al., 2009). These examples underline the importance of monitoring environmental changes, whether or not they are related to human activities, as they affect the water resources.

Changes in the environment are determined by a combination of variables in constant interaction. In the Sahel, the landscapes result from a balance between natural pressure, which tends to select a vegetation cover in balance with climate pressure, and human pressure. Human pressure generally tends to degrade the environment by decreasing natural biomass and by modifying the surface features and local infiltration conditions (Diello et al., 2005). This hypothesis was challenged by Fairhead \& Leach (1998): man maintains a wooded park while without him, fire burns all the vegetation at regular intervals.

Population pressure is also at the heart of much debate on how it is associated with environmental changes. As early as the 1930s, human (and climatic) causes of the environmental degradation in the Sahel were being debated (Stebbing, 1935, 1938). These debates intensified after the droughts of the 1970s and 1980s and in the early 1990s before the 1992 World Conference on the Environment in Rio: expansion of cultivated lands, overgrazing, overcutting of wood, and bushfires were repeatedly mentioned. These interactions between climate, populations and their environment are the driving dynamics of surface features in the Sahel, which play a major role in runoff processes.

The major goal of this study is thus to better describe and model the impact of changes in land use/land cover on runoff in the Sahel.

In section 1, we define our study area, the Sahel, and its climatic context, and present the rainfall-runoff conceptual model and data on the Nakanbé basin, which is representative of Sahelian hydroclimatic conditions.

In section 2, we analyse the performance of a rainfall-runoff conceptual model and monitor the behaviour of one of its parameters in response to global changes.

In section 3, we describe and analyse the factors responsible for environmental changes that affect surface features and ultimately the infiltration and the runoff capacity of the soils. We also discuss population dynamics in the Nakanbé basin. Finally, we discuss the relationships between population dynamics and the dynamics of environmental indicators.

In section 4, we suggest how the performances of the GR2M conceptual hydrological model can be improved.

\section{SECTION 1: GEOGRAPHICAL, CLIMATIC AND METHODOLOGICAL CONTEXT}




\section{GEOGRAPHICAL CONTEXT}

Etymologically, the term Sahel comes from the Arabic word sahil, meaning "shore", i.e. the southern "shore" of the Sahara. This is a simplistic definition as anyone crossing Sahel areas will encounter a highly heterogeneous set of environmental and social situations. This diversity, which results from different combinations of physical data, methods of exploiting the environmental and socio-economic conditions, makes it a complex environment whose limits are difficult to define (see figure 1 and 2 where the limits are different because of different considerations).

Based on Casenave \& Valentin's (1988) hydrological definition of the Sahelian zone, we take the annual $200 \mathrm{~mm}$ isohyet as the northern boundary and the annual $750 \mathrm{~mm}$ isohyet as the southern boundary, (isohyets were calculated for the period 1951-1989) (fig. 2). The southern limit corresponds to the disappearance of the phenomenon of degradation of the river system and to a minimum annual runoff coefficient $<1 \%$ (Mahé et al., 2003, Mahé \& Paturel, 2009), which increases to the north and to the south of this limit, either by saturation excess flow (Sudanian zone to the south) or surface runoff due to the sealing of degraded areas and/or low water holding capacity to the north (Descroix et al., 2009).

We focused our study on the Nakanbé basin at Wayen in Burkina-Faso (fig. 2) considered as representative of runoff conditions in the Sahel.

\section{CLIMATIC CONTEXT}

The Climatic Research Unit (UEA, Norwich, UK) provides rainfall and other climatic variable grids to calculate monthly potential evapotranspiration (PET) for $1 / 2$ degree square over the entire West Africa (New et al., 1999, 2000). The monthly flow data comes from the SIEREM database (Boyer et al, 2006; www.hydrosciences.fr/sierem).

Table 1 shows that despite the average decrease in rainfall over the catchment area in the 1970s, the runoff coefficient has increased.

Analysis of long time series of rainfall data until recent years indeed shows that the Sahel has experienced several drought periods, but not regularly recurrent (fig. 3).

Since 1950, the Sahel has experienced 20 years in which rainfall was higher than usual mostly followed by dry to very dry years (Carbonnel \& Hubert, 1992; Mahé et Olivry, 1995; Khodja et al., 1998; Paturel et al., 1998; Mahé et al., 1999; Nicholson et al., 1999; Ouedraogo, 2001).

\section{METHODOLOGICAL CONTEXT}

\section{FAO SOIL MAP}

In its "Soil Map of the World" (1981), the FAO defines seven classes of soils whose ranges of water holding capacity (WHC) are determined based on their agro-pedological soil characteristics (table 2) such as root depth, soil particle size, vegetation cover, and standardized suction limits (wilting point and field capacity).

In the great majority of river basins in West Africa, the performances of the rainfallrunoff models are improved if one uses the values of the upper limit of the ranges of WHC (maximum WHC) published by the FAO (Dezetter et al., 2008). For the Nakanbé basin at Wayen, Figure 2 shows their spatial distribution at the mesh scale of $1 / 2$ degree square. According to our geographical reference, the Nakanbé basin overlaps 17 meshes. Details on the calculation of the mean WHCs by $1 / 2$ degree squares can be found in Dieulin et al. (2006). 
DESCRIPTION OF THE GR2M MODEL

The GR2M model (http://webgr.irstea.fr/; fig. 4) was developed by Kabouya (1990). For a complete description of the model see Makhlouf and Michel (1994). Its main advantage lies in its simplicity:

- a soil reservoir $(\mathrm{H})$ controls the production function and is characterised by its maximum capacity A;

- a gravity water reservoir (S) controls the transfer function.

Based on the NS criterion (Nash \& Sutcliffe, 1970), preliminary calibration tests of the four model parameters on several West African basins led to a few modifications of this version of GR2M (Ouedraogo, 2001; Lubès-Niel et al., 2003):

- the parameter $\alpha$ is set to 0 ;

- A is equated to the WHC data extracted from the FAO soil map of the world;

- the GR2M model is spatially distributed to a half-degree square resolution (about $2500 \mathrm{~km}^{2}$ ): runoff is computed for each mesh of a basin, independently of the other meshes, and for each time step. The resulting total flow at the basin outlet is obtained by summing the weighted elementary contributions of the different meshes that comprise the basin.

\section{SECTION 2: USING A RAINFALL-RUNOFF MODEL IN THE SAHEL}

\section{PERFORMANCES OF GR2M IN THE NAKANBÉ BASIN AT WAYEN}

We tested the performance of GR2M in terms of the NS criterion using several calibration and validation periods of different lengths (5 to 25 years) on the Nakanbé basin (table 3 ). The main findings are as follows:

- the NS calibration values range from 50 to 75: these values are lower for periods including the abrupt climate change which occurred in the 1970s; the quality of the calibrations is much lower than that obtained in the majority of basins in West Africa (Mahé et al., 2005c);

- the values of validation NS obtained in the process, particularly before and after 1970, are generally below 50 except for long periods of calibration / short periods of validation;

- runoff calculated during the flood period is underestimated by about $2 / 3$ compared to observed runoff;

- however, the shape of the hydrograph and the month of the flood peak, are respected.

These results show that the calibrated parameters are likely to differ significantly for the two time series used, before and after 1970.

Other tests showed that by modifying the maximum capacity A of the soil reservoir in the GR2M model, we modulate the net rainfall available for runoff: the higher the A value, the lower the net rainfall, and vice versa.

\section{EXPLORING AN «OPTIMAL » WHC FOR THE NAKANBÉ BASIN AT WAYEN} Based on our knowledge of the rainfall variability of the region, we defined three periods: 1965-1972, 1973-1986 and 1987-1995. The year 1972 corresponds to the statistical break in the flow time series of the Nakanbé in Wayen (Mahé et al., 2005a); the driest years in the basin and a sharp deterioration of the surface features were observed between 1973 and 1986; and there was slight recurrence of the rains between 1987 and 1995 (L'Hote et al., 2002, 2003) and a marked slowing down in the degradation of surface features. We tried to find the optimum for A "step by step" to improve the performance of the model. For a given period, we calibrated the model using the FAO value of the WHC (133 $\mathrm{mm}$ for Wayen). The model 
was validated against two other periods. In each of the other two periods, we varied the value of the WHC of the basin between 5 and $400 \mathrm{~mm}$ and stored the corresponding NS values.

The three findings of this analysis are (table 4):

- the use of the WHC value given by FAO (WHC $=133 \mathrm{~mm}$ ) makes it difficult to simulate the period 1973-1986, which differed considerably from the two other periods;

- it is possible to adjust the heights of the reservoir to significantly improve the NS values (though still quite small in absolute terms) for each period of our study;

- several tests showed that between 1965-1972 and 1973-1986, the WHC should decrease and between 1973-1986 and 1987-1995, it should slightly increase, to obtain higher values of NS.

\section{DISCUSSION}

These results should be compared with previous "field" measurements and observations which reveal profound environmental changes in the Sahel. Mahé et al. (2005a) reported a marked change in land use between 1965 and 1995 in the Nakanbé basin and a link between the increase in cultivated land and bare land, and increased runoff coefficients. It thus appears possible to establish a link between changes in the surface features and the A parameter, controlling the production function of GR2M, and to try to take the changes in surface features into account in the conceptual model, which is the subject of the following section. As recommended by Gan and Burges (1990), we have to be careful not to state that our model parameters have a physical meaning. We prefer to assume that the stability / instability of the parameters of a conceptual model can result in an apparently stable / instable hydrological behaviour of the basin; but we are talking about hydrological behaviour and not a physical state. This justifies the use of GR2M in this study.

\section{SECTION 3: DESCRIPTION AND ANALYSIS OF INDICATORS OF THE ENVIRONMENTAL DYNAMICS}

In the Sahel, most arable land is now used for agriculture, in different proportions depending on the country. Ancestral practices ensured part of the land was left fallow, i.e. without crops for several some years to let soil properties regenerate naturally, with regrowth of natural vegetation. But, the fallow periods have been reduced because the population is growing rapidly. The expansion of cropping has changed the surface properties of the soil much faster than climate itself, as described by Fournier et al. (2000). Knowing the close relationship between the surface soil properties and soil infiltration capacity, we used environmental indicators related to land use change, together with runoff coefficients from dedicated studies at the local level, to test to what extent these changes in soil surface/subsurface properties can modify river runoff, even at the scale of large basins. Time series of indicators have to be created before integrating them in the simple but robust GR2M model.

\section{DEFINITION OF THE INDICATORS}

The dynamics of surface features is the result of interactions (Blaikie and Brookfield, 1987):

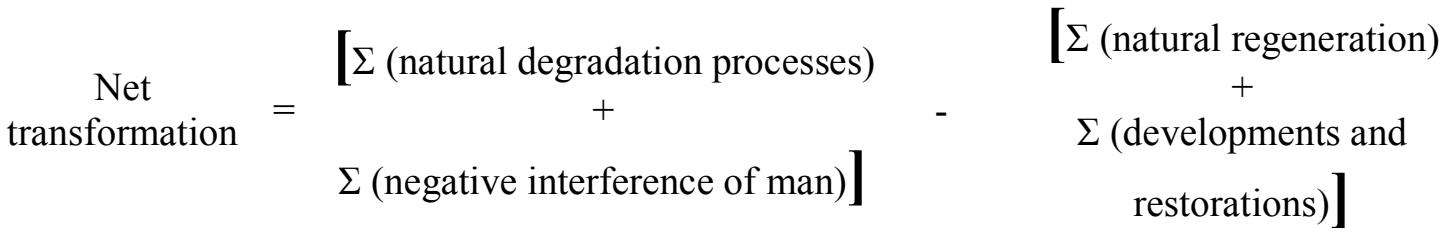


Two groups of factors, natural and anthropogenic, which influence environmental changes, emerge from this equation:

- Natural processes of degradation and regeneration of the environment are governed by climatic, physical and pedological factors (soil types, topography and the type of land cover). Rainfall and evapotranspiration are among the most critical climatic factors which almost entirely control the state of the environment in the Sahel. Related physical and pedological factors give the environment its ability to be degraded and/or regenerated.

- One of the main drivers of environmental change is land use change due to human activities. Following the increase in population in recent decades, farmers have shortened, and often eliminated fallow periods entirely. The only way to increase production is then to increase cultivated areas, so farmers began to clear new areas, to till despite steep slopes and to colonize marginal lands that are vulnerable to erosion. Such overexploitation of natural resources in the context of the continuing decrease in rainfall has resulted in environmental degradation.

A simple analysis of human activities in the Sahel shows that there are four modes of transformation of the environment. Put simply:

- soil degradation: drying out of the vegetation cover followed by soil crusting and barer soil under the combined effect of human actions and climate,

- cultivation: vegetation clearing and conversion into crop fields,

- fallowing: soil and vegetation regeneration, even if this land transformation technique is gradually disappearing due to population growth and agricultural pressure,

- new agro-pastoral practices aimed at promoting some regeneration of the environment commonly known as water and soil conservation techniques: stone bunds, zaï, halfmoons, grass strips, mulching, tree planting, manuring, hedges, etc.

From these transformation techniques, we can deduce three main types of land cover: soils with natural vegetation (including fallow), cultivated soils, bare (degraded and crusted) soils to which we can add water bodies (reservoirs), whose surface area increased significantly after 1975 (Mahé et al., 2002). These key characteristics of the dynamics of the environment have been identified as indicators of the dynamics of surface features, informing us on the importance of human and/or climatic pressure on the Sahel land cover. The changes in land cover are measurable in time and space after processing satellite images or aerial photographs.

\section{CHANGES IN THE INDICATORS OF ENVIRONMENTAL DYNAMICS OVER TIME AND IN SPACE}

We chose satellite image processing which combines an object approach (multispectral segmentation - ENVI software) and an approach based on computer aided photo interpretation, which enables the identification and delineation of thematic units directly on the image (Diello et al., 2006). Based on a 1972 Landsat-1 MSS, 1986 and 1992 Landsat-5 TM and 2002 and 2003 Landsat-7 ETM + , land cover maps of the Nakanbé basin for the four time periods were established (fig. 5) (Diello, 2007).

These maps show that the areas of bare soil increased sharply between 1972 and 1986, then increased more slowly until they stabilized. Changes in cultivated areas in the basin accelerated in two stages during the period 1972-2002. Between 1972 and 1992, cultivated areas increased sharply from $8700 \mathrm{~km}^{2}$ to $13700 \mathrm{~km}^{2}$. This increase in acreage occurred mainly at the expense of the natural vegetation which decreased from $52 \%$ to $17 \%$ of the basin. Between 1992 and 2002, the cultivated areas in the basin were only slightly modified. Marchal (1977) noted that in the Yatenga Province (northern part of the Nakanbé basin), 80\% of more fertile land was already being cultivated continuously and that $40 \%$ of the total cultivated land was marginal and degraded (with low crop yields). A more recent study 
(Drabo et al., 2003) also reported a sharp reduction in the availability of arable land throughout Burkina Faso. It is likely that in much of the Nakanbé basin, arable land has been almost completely cultivated since the 1990s.

\section{POPULATION DYNAMICS ON THE BASIN FROM 1960 TO 1996}

No satellite data is available before 1972, i.e. before the abrupt climate change in the Sahel. It is thus impossible to assess any changes in land cover before 1972 at the basin scale, and consequently impossible to correlate such changes with runoff data, which did exist before 1970. To solve this problem, we decided to work with population data, which is available at the basin scale thanks to the general population census in Burkina Faso (General Census of Population and Housing of Burkina Faso). We hypothesised that due to the very low level of mechanisation of agriculture, and hence very dependent on human labour, the fraction of cultivated area is correlated with the population.

The population model we used is one that emerged after the Second World War, the concept of demographic transition (Notestein, 1945). The hypothesis behind the demographic transition model assumes that birth and mortality follow an anti-logistic function (eq. 1) which leads to a logistic model (flattened curve or sigmoid "S" curve) of the population (eq. 2) (Artzrouni, 1986; Hillion, 1986).

$$
x(t)=C-\frac{k}{1+e^{-r\left(t-t_{0}\right)}} \quad \text { eq. } 1
$$

where $\mathrm{C}$ is the initial value of the phenomenon studied (birth rate, death rate), $\mathrm{k}$ is the magnitude of the variation of the phenomenon studied (initial value - end value), $t_{0}$ the time of the inflection point of the curve and $r$ the braking coefficient of the modelled phenomenon.

$$
x^{\prime}(t)=\frac{k^{\prime}}{1+e^{-r^{\prime}\left(t-t_{0}^{\prime}\right)}} \quad \text { eq. } 2
$$

where $\mathrm{k}^{\prime}$ is the initial value of the population, $\mathrm{t}_{0}{ }_{0}$ the time of the inflection point of the curve and $r$ the braking coefficient of the population model.

Based on the existing census and population model parameters calibrated at the country scale (Ruas and Benoit-Cattin, 1991; United Nations projections (http://esa.un.org/unpp), the logistic model was calibrated at the scale of the Nakanbé basin at Wayen (Fig. 6).

\section{INTER-RELATIONS BETWEEN POPULATION DYNAMICS AND INDICATORS OF ENVIRONMENTAL DYNAMICS}

Available satellite images of the Nakanbé basin during the period 1972-2002 only provide four "snapshots" of the basin: the situation around 1972, 1986, 1992 and 2002, but no information between these dates. The objective was thus to find a way to bridge these gaps. We can write at any time:

$$
\mathrm{S}_{\mathrm{bv}}=\mathrm{S}_{\mathrm{C}}+\mathrm{S}_{\mathrm{Vg}}+\mathrm{S}_{\mathrm{Bs}}+\mathrm{S}_{\mathrm{Wb}} \quad \text { eq. } 3
$$

where $\mathrm{S}_{\mathrm{bv}}, \mathrm{S}_{\mathrm{C}}, \mathrm{S}_{\mathrm{Vg}}, \mathrm{S}_{\mathrm{Bs}}$ and $\mathrm{S}_{\mathrm{Wb}}$ are the respective areas of the catchment, cultivated areas, areas with natural vegetation, bare soil and water bodies.

CULTIVATED AREAS AND AREAS WITH NATURAL VEGETATION

From the available information and the literature, it is simple to predict the changes in the cultivated areas: 
- at the time when the basin was sparsely populated (before 1950), yields on cultivated areas covered the food needs of the populations. Cultivated areas were at their lowest level and only fluctuated slightly;

- from 1950 to 1970 , the population increased which resulted in additional demand for food, but the climatic conditions in the 1950s and 1960s produced better yields, thus only requiring moderate extension of the cultivated areas;

- after 1970, the drought reached a climax in the 1980s. As the population continued to grow, farmers reduced the length of fallow of their fields and increasingly cleared the natural habitat, including good arable land but also more marginal lands;

- at the end of the 1980s and in the early 1990s, the arable area was completely cultivated and stable, as were bare soils. To meet the food demand, farmers modernised their means of production, and adopted soil conservation techniques.

This scenario is close to the demographic transition model of population with an "S" curve mentioned above, and we therefore chose a logistic evolution model to express the dynamics of the cultivated areas in the Nakanbé basin at Wayen. The development of cultivated areas occurred mainly at the expense of areas of natural vegetation, by symmetry it is thus possible to build their logistic evolution model (fig. 7).

\section{WATER BODIES AND BARE SOILS}

As part of its "Programme National de Gestion de l'Information sur le Milieu (PNGIM)" in 1999, Burkina Faso made an inventory of reservoirs identified throughout the country. This database includes around 300 reservoirs in the Nakanbé basin (1,500 nationwide). By linking these results with those obtained from image processing, when available, it is possible to identify changes the surface area of the water bodies in the basin. Knowing the size of the basin, the cultivated area, the area with natural vegetation and the surface area of the water bodies, and on the basis of equation 3 , it is possible to deduce changes in the extent of bare soils.

\section{DISCUSSION}

Figure 8 summarizes the results obtained in the Nakanbé basin at Wayen regarding changes in the four environmental indicators and in the population during the period for which flow data is available.

We developed a method to characterise the dynamics of changes in the indicators between the dates of the images, taking into account the population dynamics and the cropping practices of the populations living in the basin.

Even if the results obtained usually reflect interactions between the population and the resources at basin level, the following care should be taken when interpreting the numerical results:

- assumptions or approximations were made to fix some starting or ending values to model the changes in the environmental indicators

- uncertainties related to the data: hydro-pluviometric data, quality of the images and how they are processed; data from various censuses used;

- the fact that the population model does not account for the phenomena of immigration and emigration in the basin. The region has gone through several political crises in recent years which led to a major movement of Burkinabe people back to their region of origin. Many of these returning people settled around major metropolitan areas like Ouahigouya in the Nakanbé basin. As underlined by Drabo et al. (2007), profound changes in land issues are ongoing and there have been major population migrations towards areas more favourable to agriculture. 
Despite these imperfections, we achieved one of the goals we set for the study: identifying indicators of human and/or climatic pressure in the basin (proportions of areas with natural vegetation, crops, bare soil and water bodies) and, using a population model based on the demographic transition model, developing a scenario of annual changes in these indicators. These indicators represent the interactions between climate, the populations and their environment, which are the driving dynamics of surface features in the Sahel. In the Sahel, these dynamics are themselves responsible for the distribution of rainfall between infiltration and runoff and hence water resources.

The second section of this article showed that better performances of the GR2M model can be obtained by numerical adjustment of the maximum capacity of the soil reservoir. Using the annual time series of indicators of land-cover described here, section 4 runs the GR2M model, taking the annual changes in land cover into account. We expected that changing the maximum capacity of the reservoir in the model would enable the hydrological model to better simulate the increase in runoff from this Sahelian river since the drought.

\section{SECTION 4: IMPROVING THE PERFORMANCES OF THE GR2M CONCEPTUAL HYDROLOGICAL MODEL}

\section{INDICATORS OF ENVIRONMENTAL DYNAMICS}

\section{WHC DATA OF THE SOIL MAP OF FAO}

The land use indicators were calculated according to the classes defined by Mahé et al. (2002, 2005a), supplemented by Diello et al. (2006): soils with natural vegetation (including fallow), cultivated lands, bare soil (degraded and crusted) and water bodies (natural and artificial). A mean WHC, from the WHC of the various soil classes that constitute it, is attributed to each mesh of a $1 / 2$ degree square on the Nakanbé basin at Wayen.

The maximum capacity of the soil reservoir A in the GR2M model is assimilated to the WHC value. The WHC value was calculated on the basis of the soil map prepared by FAO (FAO-Unesco, 1974-1981). The maximum capacity of the soil reservoir A deduced from the FAO soil map represents a source of reference information on water holding capacities at world scale. These data reflect the condition of the environment at a date that we are unable to identify precisely. Indeed, the first soil maps published by FAO date back to 1973. Data and measurements used to draw the first maps thus date back a few years before their date of publication.

On the other hand, one of the only maps of soil types at the level of the African continent is the soil map of the African Commission for Technical Cooperation (CCTA, 1963). If this map was used as a source of information for the first FAO soil map, it would mean that the sources of information used by FAO date back to before 1963. A simple hypothesis is to consider that the FAO data correspond to the state of the basin in 1965, starting date of the hydrological observations used in the present study.

The passage of a WHC from one year to another one is done according to equation 4, following the rules for the passage from one soil type to another as described in figure 9 (the percentages of each class being drawn from figure 8).

Equation 4 (example for the natural vegetation area):

$$
\begin{gathered}
W H C_{V g} \longrightarrow W H C=\left[\alpha \%+\beta \% \frac{K r V g}{K r C}+\gamma \% \frac{K r V g}{K r B s}+\delta \% \frac{K r V g}{K r W b}\right] W H C_{V g} \\
\text { eq. } 4
\end{gathered}
$$


where $\alpha, \beta \gamma$ and $\delta$ are, respectively, percentages of variation in natural vegetation $(\mathrm{Vg})$, cultivated (C) and bare soils (Bs) and water bodies (Wb) and $\mathrm{KrVg}$ is the runoff coefficient of natural vegetation area. This example can be generalised to other type of land covers. The implicit assumption is any variation in the runoff coefficient due to the modification of the environment results in an opposite variation in the same proportion of the water holding capacity.

THE RELATIONSHIP BETWEEN LAND USE, RUNOFF COEFFICIENT AND MAXIMUM CAPACITY OF THE SOIL RESERVOIR (A)

The annual average runoff coefficient (RC) differs for each class and also varies from the north to the south of the basin (Table 5).

The RCs of Fournier et al. (2000) match the environment of the southern part of the basin, and are usually lower than those of Yacouba et al. (2002), which correspond to the environment of the northern part of the basin, for an average of all types of land uses. The calculated WHC are slightly higher with the RCs of Fournier (Figure 10). According to Fournier et al. (2000), the RC increases proportionally to the decrease in the WHC. These results were obtained after many years of work by several teams in several countries in West Africa as part of the International "Jachères" program, funded by the EU. The RC increases with a decrease in the vegetation, and the WHC was at a maximum value in 1965 when natural vegetation still occupied most of the surface area of the basin. The WHC then decreased with the increase of the cultivated and bare soils and water bodies.

\section{GENERATION OF MAXIMUM CAPACITY OF THE SOIL RESERVOIR (A) FILES FOR USE WITH GR2M}

The aim is to compare the performance of the hydrological model based on the type of WHC file used. The WHC "test" file is called fixed WHC, where the value of WHC is calculated for each $1 / 2$ degree square from FAO data.

We generated several files of "time-varying WHC" according to a logistic model of population "WHC logistics", with either the RCs of Fournier (2000) or Yacouba (2002).

\section{PERFORMANCES OF THE GR2M WITH THE TIME-VARYING SERIES OF A: CASE OF THE NAKANBÉ BASIN AT WAYEN}

We compare the performances of the GR2M model with fixed WHC and the time-varying WHC, and study model sensitivity to various data sources and soil runoff coefficients.

\section{PROTOCOL AND CHOICE OF CALIBRATION-VALIDATION PERIODS}

The abrupt climate change that occurred around 1970 in the Sahel introduced more heterogeneity in climate data sets, and also a change in the hydrological functioning of the basin (Mahé \& Paturel, 2009), the choice of calibration periods is thus important for the specification of the model parameters. We chose several calibration periods which are characteristic of different climatic conditions: 1965-1972, 1973-1986 and 1987-1995. We performed cross calibration-validation over several periods. In the first set of data, we used the three periods to search for optimums for the WHC/A reservoir value. Another longer period of calibration (1965-1986) was also defined. This period was chosen to provide the model with a series of calibration data representative of a wider range of responses by the basin including highly variable climate conditions, and the validation period was from 1987 to 1995.

\section{RESULTS OF THE GR2M PERFORMANCES WITH THE TIME-VARYING WHC/A RESERVOIR}


The results are summarised in table 6, which shows the values of NS criterion for calibration and validation. These results show that performances vary as a function of the choice of the calibration period.

The NS coefficients are significantly higher in calibration with the time-varying A for two periods except 1973-1986 and 1965-1985, while for 1965-1972 and 1987-1995, the results with fixed or time-varying A are quite similar. But it should be noted that, among many other trials performed, when using a slightly different calibration period like 19651975, rather than 1965-1972, which means that it includes the first very dry years of the Sahelian drought, the NS value is much higher with the time-varying A than with the fixed A. Over a long period within which the environment became drier, the fact that the model performance improved with the time-varying A indicates, in our opinion, that this method is relevant.

Validation was better with the time-varying WHC than with the fixed WHC for almost all periods of calibration and validation. The NS values obtained for the calibration period 1965-1985 and 1986-1995 validation exceed 0.7, which makes them suitable for simulations of future hydrological regime, although with caution, as the performance remains modest, and taking into account the fact that we do not know how the A will continue to change in the future.

The simulations with the fixed A satisfactorily reproduced the shape of the hydrographs and the date of the flood peak, but still underestimated average monthly flows (Fig. 11) whether with the fixed or time-varying A. With the time-varying A the first two months of flooding, (June and July) are much better represented than with the fixed A, especially for the period 1987-1995. Figure 12 shows the improvement in the performance of the model (NS) with the time-varying A compared to the fixed A for two validation periods (1973-1986 and 1987-1995) and 2 RC values (Fournier or Yacouba) associated with the calibration period 1965-1972. The values reached with the use of time-varying WHC allow its use for the simulation of water resources for the future.

The best performance of GR2M in validation with the time-varying WHC reflects its adaptation to climate and environmental change, compared to use with the fixed WHC.

\section{CONCLUSION}

In this paper, our aim was to improve the quality of the simulations of the hydrograph of monthly flows of the Nakanbé river basin $\left(20000 \mathrm{~km}^{2}\right.$ at the Wayen gauging station) in northern Burkina Faso, representative of the Sahel zone, by integrating the dynamics of the Sahel environment in a global hydrological model such as GR2M.

This work has two original features:

- the construction and use of a time-varying soil dataset, which changes every year based on changes in land use observed on satellite images,

- the use of population data to run a demographic model used to calculate annual values of four land cover classes, on the basis of a correlation between land-use indices and the population curve.

The results point to an improvement in the results of the hydrological modelling when the calculation of the WHC takes changes in land-cover/use into account. The model is able to reproduce the Sahelian paradox of more runoff over time with less rain, which has been observed since the middle of the 1970s.

The demographic model we used is widely used in population projections at a large scale. It provides trends in over a long period of time, and is naturally sensitive to the quality and representativeness of the data used. It is for instance difficult to properly assess some determinants of population dynamics -such as migration- due to unpredictable conflicts that can deeply affect the local economy and its environment, and to population displacements due 
to land shortage, drought episodes, the attraction of cities and/or the demand for labour in more developed areas.

Other results (not shown) indicate that the use of logistic WHC (time-varying) in GR2M leads to a better performance when the WHC is fixed or evolves linearly. We obtained an average of $67 \mathrm{NS}$ in calibration and 57 in validation. It should be noted that in a significant number of cases the performance is much better than these averages. Around half of the NS index exceeds 70 . We obtained NS values of the same order of magnitude in the validation period 1987-1995 with parameters from the calibration over the period 1965-1986. The latter case corresponds to the best simulation. The length of its calibration period (20 years) allows the model to scan a larger number of hydroclimatic situations during calibration. This subsequently allows better replication of the observed flows.

Three points need to be kept in mind concerning the simulation hydrographs obtained:

- the shape of the hydrograph is well reproduced,

- the dates of flood peaks are well simulated,

- peak flood flows are mostly underestimated by the model. Especially that of September, which the model is practically incapable of calculating, unlike the flood in August, which is relatively well simulated.

These results are a very significant improvements over those normally obtained with the fixed WHC or time-varying linearly over time. Indeed, comparative analysis of performances showed that in GR2M, the use of time-varying WHC data following a logistic model of population improves performances.

However this is an exploratory study and several points require further investigation, including the relationship between the runoff coefficient and WHC, to allow for environmental dynamics to be better taken into account in the GR2M hydrological model. Other conceptual models should also be tested. 


\section{REFERENCES}

Albergel J., Ribstein P., Valentin C. 1986. L'infiltration: quels facteurs explicatifs? Analyse des résultats acquis sur 48 parcelles soumises à des simulations de pluie au Burkina Faso. In Journées hydrologiques de l'ORSTOM Montpellier, France. Paris, ORSTOM. 25-48.

Ardoin-Bardin S., Dezetter A., Servat E., Paturel J.-E., Mahé G., Niel H., Dieulin C. 2009. Using general circulation model outputs to assess impacts of climate change on runoff for large hydrological catchments in West Africa. Hydrological Sciences Journal 54: 77-89. Artzrouni M. 1986. Une nouvelle famille de courbes de croissance: application à la transition démographique. Population 3: 497-509.

Blaikie P., Brookfield H. 1987. Land degradation and society. Routledge, London and New York, 296 pp.

Boyer J.F. Dieulin C. Rouché N., Cres A., Servat E., Paturel J.-E., Mahé G. 2006. SIEREM : an environmental information system for water resources. In Climate variability and change : hydrological impacts, La Havane, Cuba. AISH Publ. 308: 19-25.

Carbonnel J.P., Hubert P. 1992. Pluviométrie en Afrique de l'Ouest soudano-sahélienne : remise en cause de la stationnarité des séries. In L'aridité: une contrainte au développement: caractérisation, réponses biologiques, stratégies des sociétés, Le Floc'h E. (ed.), Grouzis Michel (ed.), Cornet Antoine (ed.), Bille Jean-Claude (ed.). Paris : ORSTOM. 37-51.

Casenave A., Valentin C. 1988. Les états de surface de la zone sahélienne. Influence sur l'infiltration. CEE / ORSTOM, multigr. Paris, 202pp.

Casenave A., Valentin C. 1991. Influence des états de surface sur l'infiltration en zone sahélienne. In Niamey Workshop on Soil Water Balance in Soudano-Sahelian Zone, Niamey, Niger. IAHS Publ. 199: 99-108.

C.C.T.A. 1963. Carte des sols d'Afrique. Carte en sept feuilles au 1/5 000000. Descroix L., Mahé G., Lebel T., Favreau G., Galle S., Gautier E., Olivry J.C., Albergel J., Amogu O., Cappelaere B., Dessouassi R., Diedhiou A., Le Breton E., Mamadou I., Sighomnou D. 2009. Spatio-Temporal variability of hydrological regimes around the boundaries between Sahelian and Sudanian areas of West Africa: a synthesis. Journal of Hydrology 375 (1-2): 90-102.

Descroix L., Genthon P., Amogu O., Rajot J.-L., Sighomnou D., Vauclin M. 2012. Change in Sahelian Rivers hydrograph: The case of recent red floods of the Niger River in the Niamey region. Global and Planetary Change 98-99: 18-30.

http://dx.doi.org/10.1016/j.gloplacha.2012.07.009

Dezetter A., Girard S., Paturel J.-E., Ardoin S., Mahé G., Servat E. 2008. Simulation of Runoff in West Africa: is there a single data-model combination that produces the best simulation results? Journal of Hydrology 354: 203- 212.

Diello P., Mahé G., Paturel J.-E., Dezetter A., Delclaux F. 2005. Relations indices de végétation - pluie au Burkina Faso : cas du bassin versant du Nakanbé. Hydrological Sciences Journal, 50: 207-222.

Diello P., Paturel J.-E., Mahé G., Karambiri H., Servat E. 2006. Méthodologie et application d'une démarche de modélisation hydrologique prenant en compte l'évolution des états de surface en milieu sahélien d'Afrique de l'Ouest. In Water Resource Variability:

Processes, Analyses and Impacts, La Havana, Cuba. IAHS Publ. 308: 691-697

Diello P. 2007. Interrelations Climat, Homme, Environnement dans le Sahel Burkinabé : impacts sur les états de surface et la modélisation hydrologique. Thèse, Université Montpellier II, France.

Dieulin C., Boyer J.F., Ardoin-Bardin S., Dezetter A. 2006. The contribution of GIS to hydrological modelling. In : Climate variability and change : hydrological impacts, La Havane, Cuba. AISH Publ. 308: 68-74 
Dolman A.J., Gash J.H.C., Goutorbe J.P., Kerr Y.H. Lebel, T. Prince S.D., Stricker J.N.M. 1997. The role of the land surface in Sahelian climate: HAPEX-Sahel results and future research needs. Journal of Hydrology, 188-189: 1067-1079.

Drabo I., Ilboudo F., Quesnel A., Tallet B., Marchal J.Y. 2003. Dynamique des populations, disponibilités en terres et adaptation des régimes fonciers: le cas du Burkina Faso. CICRED, FAO, Paris. 114 p.

Duley F.L. 1939. Surface factors affecting the rate of intake of water by soils. Soil Sci. Soc. Amer. Proc., 4: 60-64.

Fairhead J., Leach M. 1998. Reframing deforestation: global analysis and local realities: studies in West Africa, Global Environmental Change Series, Routledge, ISBN 0-41518591-2, $238 \mathrm{pp}$.

Fao-Unesco 1974-1981. CD-ROM: Soil Map of The World. UN Food and Agriculture Organization, Rome, Italy.

Fournier J., Serpantié G., Delhoume J.P., Gathelier R. 2000. Rôle des jachères sur les écoulements de surface et l'érosion en zone soudanienne du Burkina: Application à l'aménagement des versants. In La jachère en Afrique tropicale: Rôle, Aménagements, Alternatives. Floret C., Pontanier R. (Editors). Paris, ORSTOM. 179-188.

Gan T.Y., Burges S. 1990. An assessment of a conceptual rainfall-runoff model's ability to represent the dynamics of small hypothetical catchments: 2. Hydrologic responses for normal and extreme rainfall. Water Resources Research, 26(7): 1605-1619.

Gardelle J., Hiernaux P., Kergoat L., Grippa M. 2010. Less rain, more water in ponds: a remote sensing study of the dynamics of surface waters from 1950 to present in pastoral Sahel (Gourma region, Mali). Hydrol. Earth Syst. Sci., 14(2): 309-324

Hiernaux P., Le Houérou H.N. 2006. Les parcours du Sahel. Sécheresse, 17 (1-2) : 51-71 Hillion A. 1986. Les théories mathématiques des populations. Que sais-je? n²258, Presses Universitaires de France, Paris, 127 pp.

IPCC 2013. Climate Change 2013: The Physical Science Basis. Contribution of Working Group I to the Fifth Assessment Report of the Intergovernmental Panel on Climate Change. Stocker, T.F., D. Qin, G.-K. Plattner, M. Tignor, S.K. Allen, J. Boschung, A. Nauels, Y. Xia, V. Bex and P.M. Midgley (eds.). Cambridge University Press, Cambridge, United Kingdom and New York, NY, USA, 1535 pp.

Kabouya M. 1990. Modélisation pluie-débit au pas de temps mensuel et annuel en Algérie septentrionale. Thèse doctorat, Université Paris-sud, Orsay, France.

Khodja H., Lubès-Niel H., Sabatier R., Masson J.M., Servat E., Paturel J.-E. 1998. Analyse spatio-temporelle de données pluviométriques en Afrique de l'Ouest. Recherche d'une rupture en moyenne. Une alternative intéressante: les tests de permutation. Revue de statistique appliquée, XLVI(1): 95-110.

Legesse D., Vallet Coulomb C., Gasse F. 2003. Hydrological response of a catchment to climate and land use changes in tropical Africa; case study south central Ethiopia. Journal of Hydrology, 275(1-2): 67-85.

L'Hôte Y., Mahé G. 1996. Afrique de l'Ouest et Centrale, Précipitations moyennes annuelles (période 1951-1989). Collection des cartes ORSTOM, ORSTOM Ed., Paris.

L'Hôte Y., Mahé G., Somé B., Triboulet J.P. 2002. Analysis of a Sahelian annual rainfall index updated from 1896 to 2000. The drought still goes on. Hydrological Sciences Journal, 47(4): 563-572.

L'Hôte Y., Mahé G., Somé B. 2003. The 1990's rainfall in the Sahel: the third driest decade since the beginning of the century. Reply to discussion. Hydrological Sciences Journal, 48(3): 493-496.

Lubès-Niel H., Paturel J.-E., Servat E. 2003. Study of parameter stability of a lumped hydrologic model in a context of climatic variability. Journal of Hydrology, 278: 213-230 
Mahé G., Olivry J.C. 1995. Variations des précipitations et des écoulements en Afrique de l'Ouest et Centrale de 1951 à 1989. Sécheresse, 6(1): 109-117.

Mahé G., L'hôte Y., Olivry J.C., Wotling G. 1999. Trends and discontinuities in regional rainfall of West and Central Africa - 1951-1989. Hydrological Sciences Journal, 46(2): 211226.

Mahé G., Dray A., Paturel J.-E., Crès A., Koné F., Manga M., Crès F.N., Djoukam J., Maïga A.H, Ouedraogo M., Conway D., Servat E. 2002. Climatic and anthropogenic impacts on the flow regime of the Nakanbé River in Burkina. In FRIEND 2002 Regional Hydrology: Bridging the gap between research and practice, Cape Town, South Africa. H. Van Lannen and S. Demuth Sci. Eds. IAHS Publ. 274: 69-76.

Mahé G., Leduc C., Amani A., Paturel J.-E., Girard S., Servat E., Dezetter A. 2003. Augmentation récente du ruissellement de surface en zone soudano-sahélienne et impacts sur les ressources en eau. In Hydrologie des régions méditerranéennes et semi-arides, Montpellier, France. AISH Publ. 278: 215-222.

Mahé G., Paturel J.-E., Servat E., Conway D., Dezetter A. 2005a. The impact of land use change on soil water holding capacity and river flow modelling in the Nakanbé river, Burkina Faso. Journal of Hydrology, 300: 33-43.

Mahé G., Olivry J.C., Servat E. 2005b. Sensibilité des cours d'eau ouest-africains aux changements climatiques et environnementaux: extrêmes et paradoxes. In Regional Hydrological impacts of Climatic Change-HydroclimaticVariability, Foz do Iguaçu, Brasil. ed. by S. Franks, T. Wagener, E. Bøgh, H. V. Gupta, L. Bastidas, C. Nobre \& C. de Oliveira Galvão. IAHS Publ. 296: 169-177.

Mahé G., Rescan M., Dezetter A., Ardoin S., Dieulin C. 2005c. Water resources prediction in West and Central Africa for the 21st century. In AMMA 2005 DAKAR' First International AMMA Conference on the West African Monsoon, Dakar, Senegal.

Mahé G., Paturel J.-E. 2009. 1896-2006 Sahelian rainfall variability and runoff increase of Sahelian rivers. C.R. Geosciences, 341: 538-546.

Mahé G., Lienou G., Descroix L., Bamba F., Paturel J.-E., Laraque A., Meddi M., Habaieb H., Adeaga O., Dieulin C., Chahnez Kotti F., Khomsi K. 2013. The rivers of Africa: witness of climate change and human impact on the environment. Hydrological Processes, 27: 2105-2114.

Maklouf Z., Michel C. 1994. A two parameter monthly water balance model for French watershades. Journal of Hydrology, 162: 299-318.

Marchal J.Y. 1977. Système agraire et évolution de l'occupation de l'espace au Yatenga (Haute Volta). In: Cahiers ORSTOM. Série Sciences Humaines. ORSTOM, Paris.141-149. Nash J.-E., Sutcliffe J.V. 1970. River flow forecasting through conceptual models, discussion of principles. Journal of Hydrology, 10: 282-290.

New M., Hulme M., Jones P. 1999. Representing twentieth century space-time climate variability. Part I: development of a 1961-1990 mean monthly terrestrial climatology. Journal of Climate, 12(3): 829-856.

New M., Hulme M., Jones P. 2000. Representing twentieth century space-time climate variability. Part II: development of a 1901-1996 monthly grids of terrestrial surface climate. Journal of Climate, 13(13): 2217-2238.

Nicholson S.E. 2000. Land surface processes and Sahel climate. Reviews of Geophysics, 38(1): 117-139.

Nicholson S.E., Somé B., Koné B. 1999. An analysis of recent rainfall conditions in West Africa, including the rainy seasons of the 1997 El Niño and the 1998 La Niña years. Journal of Climate, 13(14): 2628-2640.

Notestein F.W. 1945. Population-: the long view. In Food for the world. University of Chicago Press, pp. 36-57. 
Ouedraogo M. 2001. Contribution à l'étude de l'impact de la variabilité climatique sur les ressources en eau en Afrique de l'Ouest. Analyse des conséquences d'une sécheresse persistante: normes hydrologiques et modélisation régionale. Thèse de Doctorat. Université de Montpellier II, France, 257 pp.

Paturel J.-E., Servat E., Delattre M.O. 1998. Analyse de séries pluviométriques de longue durée en Afrique de l'Ouest et Centrale non sahélienne dans un contexte de variabilité climatique. Hydrological Sciences Journal, 43(6): 937-946.

Paturel J.-E., Ouedraogo M., Servat E., Mahé G., Dezetter A., Boyer J.F. 2003. The concept of rainfall and streamflow normals in West and central Africa in a context of climatic variability. Hydrological Sciences Journal, 48: 1, 125-137.

Paturel J.-E., Barrau C., Mahé G., Dezetter A., Servat E. 2007. Impact of the climatic variability on water resources in West and Central Africa. Hydrological Sciences Journal, 52: $38-48$.

Ruas J.F., Benoit-Cattin M. 1991. Modélisation technico-démographique des futurs alimentaires du Burkina Faso. Les Cahiers de la Recherche Développement, 29.

Seaquist J.W., Hickler T., Eklundh L., Ardo J., Heumann B.W. 2009. Disentangling the effects of climate and people on Sahel vegetation dynamics. Biogeosciences, 6: 469-477

Séguis L., Cappelaere B., Peugeot C., Leduc C., Milesi G. 2003. Influence de la sécheresse et du défrichement sur les écoulements d'un petit bassin versant sahélien. In Hydrology of mediterranean and semiarids regions, Montpellier, France. IAHS Pub. 278: 429-434.

Servat E., Paturel J.-E., Kouamé B., Travaglio M., Ouedraogo M., Boyer J.-F., LubèsNiel H., Fritsch J.-M., Masson J.-M., Marieu B.. Identification, caractérisation et conséquences d'une variabilité hydrologique en Afrique de l'Ouest et Centrale. 'Abidjan'98', Abidjan, Côte d'Ivoire, 16-19 Novembre 1998. IAHS-AISH Publication, 252 :323-337 Sighomnou D., Descroix L., Genthon P., Mahé G., Bouzou Moussa I., Gautier E., Mamadou I., Vandervaere J.P., DWN-BF, Rajot J.L., Malam Issa O., Malam Abdou M., Dessay N., Delaitre E., Depraetere C., Faran Maiga O., Diedhiou A., Panthou G., Vischel T., Yacouba H., Karambiri H., Mougin E., Hiernaux P., Abdourahmane D., Adamou H. 2013. La crue de 2012 à Niamey : un paroxysme du paradoxe du Sahel ? Sécheresse, 24(1): 313.

Spiekermann R., Brandt M., Samim, C. 2013. Using high resolution imagery to detect woody vegetation and land-cover change over 50 years in the Sahel of Mali. Poster, EGU2013-11937, General Assembly, Vienna.

Stebbing E.P. 1935. The encroaching Sahara: the threat to the West African colonies. Geographical Journal, 85: 506-524.

Stebbing E.P. 1938. The man-made desert in Africa: erosion and drought. Supplement to the Journal of the Royal African Society. Vol. XXXVII, No. CXLVI: 3-40.

Valentin C. 1986. Différencier les milieux selon leur aptitude au ruissellement: une cartographie adaptée aux besoins hydrologiques. In Journées Hydrologiques de l'ORSTOM à Montpellier, ORSTOM, Coll. Colloques et Séminaires. 50-74.

Yacouba H., Da Dapola E.C., Yonkeu S., Zombre P., Soule M. 2002. Caractérisation du ruissellement et de l'érosion hydrique dans le bassin supérieur du Nakanbé (Burkina Faso). In Sème Conférence Inter-Régionale sur l'environnement et l'Eau - Envirowater 2002. Ouagadougou. 318-325. 


\section{$1 \quad$ List of Figures}

2 Figure 1: Ranking of conditioning factors for the runoff in West Africa (from Valentin, 1986

3 - limits of Sahel are based on climatic criteria)

4 - low, * medium, ** important, *** principal.

5 Figure 2: Limits of Sahel and Nakanbé basin - 200 and $750 \mathrm{~mm}$ isohyets (limits of Sahel are

6 based on hydrologic criteria) after Lhôte \& Mahé (1996) - WHC (Water Holding Capacity)

7 after FAO (1981).

8 Figure 3: Sahelian rainfall index (1896-2006) and number of stations (from Mahé \& Paturel,

9 2009). The Sahelian index is the average of the standardized deviation of each station in the

10 reference period $1896-2006$.

11 Figure 4: GR2M functionning scheme (parameters to calibrate : X1, X2, A and $\alpha$ ) - P, ETP

12 and Q : rainfall, potential evapotranspiration and runoff - P', ETP', En, Pn, Pe, H, S and Qg :

13 internal variables.

14 Figure 5: Results of the satellite images processing, determining the evolution of the land-

15 cover on the Nakanbé basin between 1972 and 2002 (from Diello, 2007).

16 Figure 6: Models of birth, mortality, demographic growth and population, calibrated for the

17 Nakanbé basin at Wayen.

18 Figure 7: Estimation of the evolution of the cultivated and of the natural vegetation surfaces

19 on the Nakanbé basin at Wayen, and calibration points corresponding to the dates of the

20 satellite images.

21 Figure 8: Estimation of the evolution of the 4 environmental indicators and of the population

22 between 1965 and 2002 for the Nakanbé basin at the Wayen gauging station.

23 Figure 9: Elements of computation of the average WHC according to runoff coefficients (see 24 eq. 4$)$. 
1

2

3

4

5

6

7

8

9

10

11

12

13

14

15

16

17

18

19

20

21

22

23

24

25

26

27

28

29

30

31

32

33

34

35

36

37

38

39

40

41

42

43

44

45

46

47

48

49

50

51

52

53

54

55

56

57

58

59

60

1 Figure 10: Evolution of the WHC on the Nakanbe basin at Wayen with FAOmax soil data and

2 runoff coefficients of Yacouba et al. (2002) and of Fournier et al. (2000) (from Diello, 2007).

3 Figure 11: Hydrographs of observed and simulated monthly discharges of the Nakanbé at

4 Wayen with fixed and time-varying (logistical) WHC for 2 different periods, after calibration

5 on the period 1965-1972.

6 Figure 12: Nakanbé basin at Wayen. NS values for time-varying WHC in regard of the NS

7 values for fixed WHC, for 2 validation periods (1973-1986 and 1987-1995) and 2 RC's values

8 (Fournier or Yacouba) associated to the calibration period 1965-1972. 


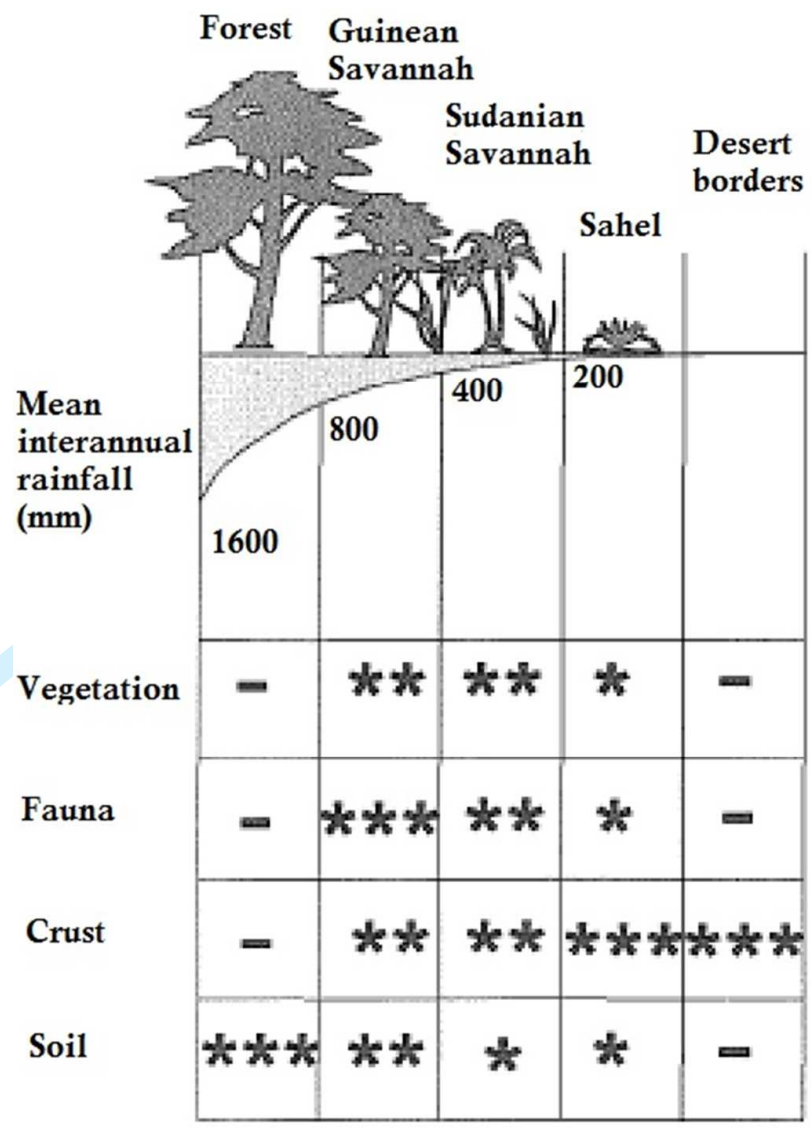




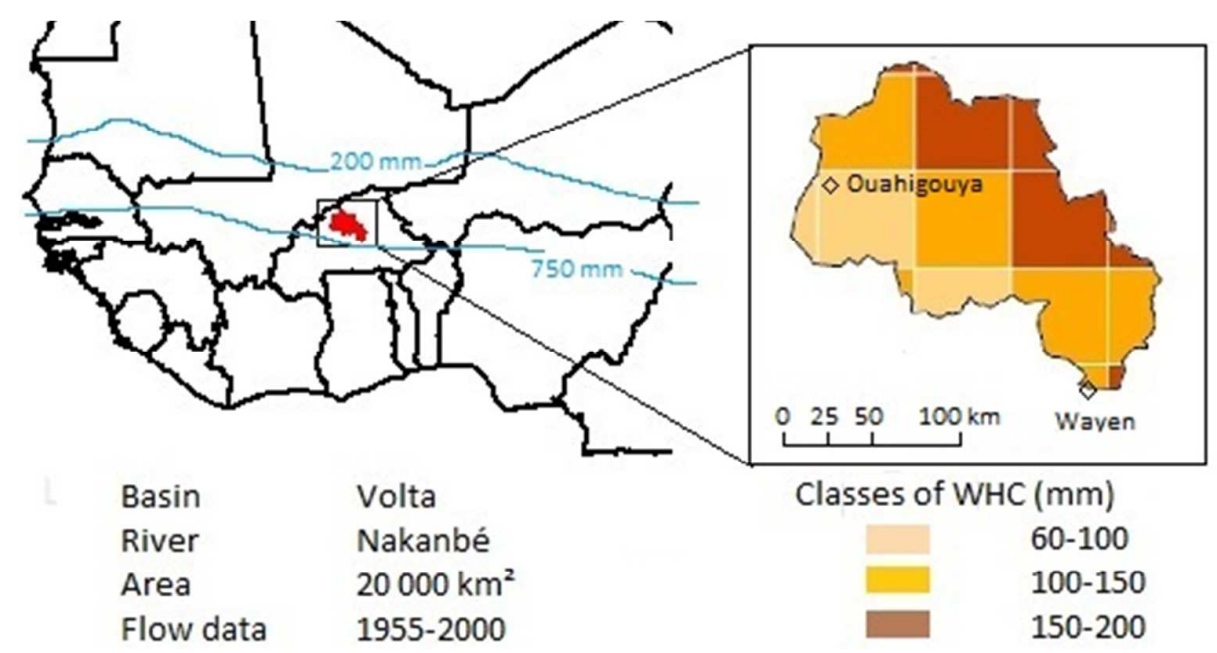

1

2

3

4

5

6

7

8

9

10

Figure 2

11

http://mc.manuscriptcentral.com/hyp 


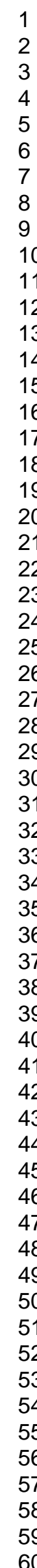

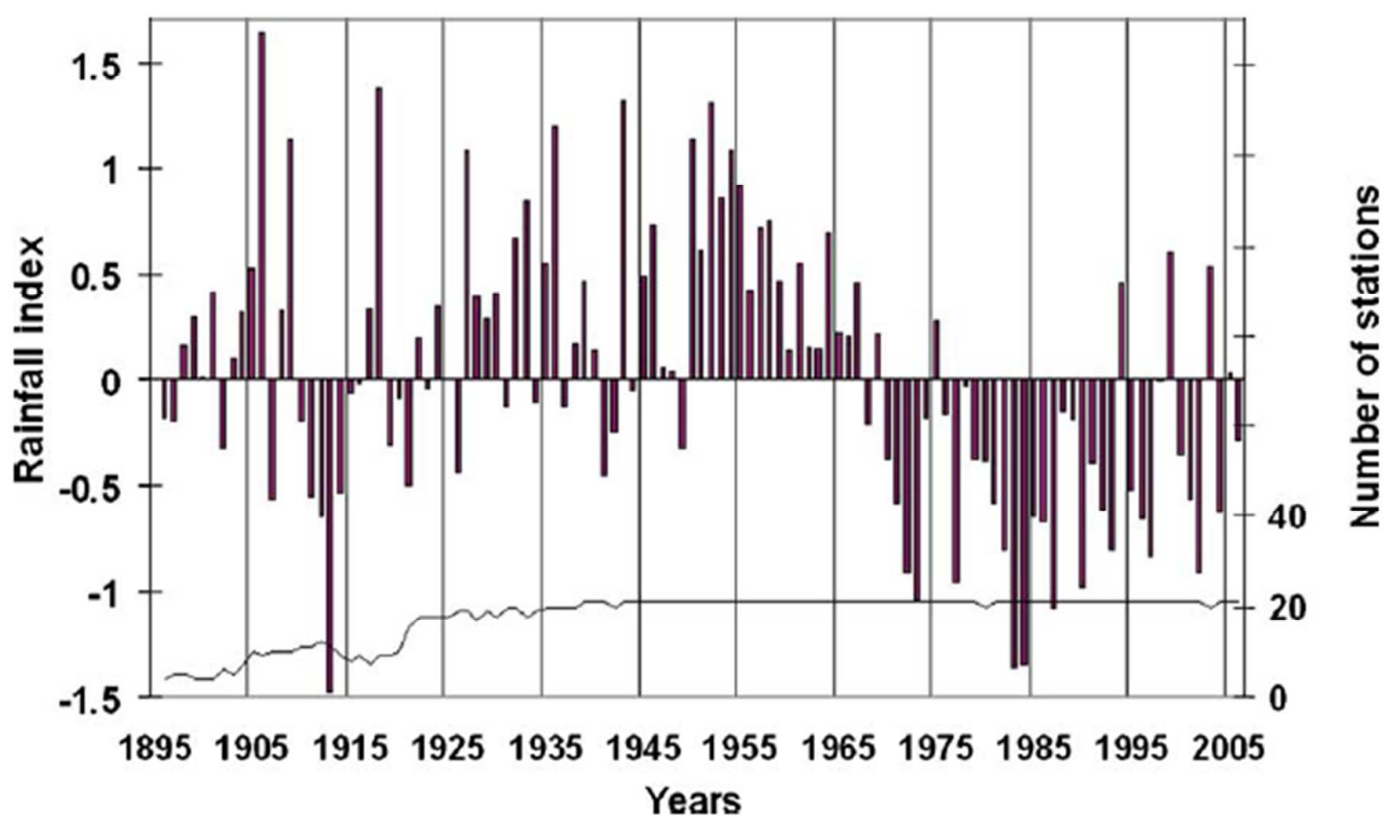

2

3

4

5

6

7

8

9

10

$11 \quad$ Figure 3

12

13

14

15

16

17

59

60

http://mc.manuscriptcentral.com/hyp 
1

2

3

4

5

6

7

8

9

10

11

12

13

14

15

16

17

18

19

20

21

22

23

24

25

26

27

28

29

30

31

32

33

34

35

36

37

38

39

40

41

42

43

44

45

46

47

48

49

50

51

52

53

54

55

56

57

58

59

60
1

2

3

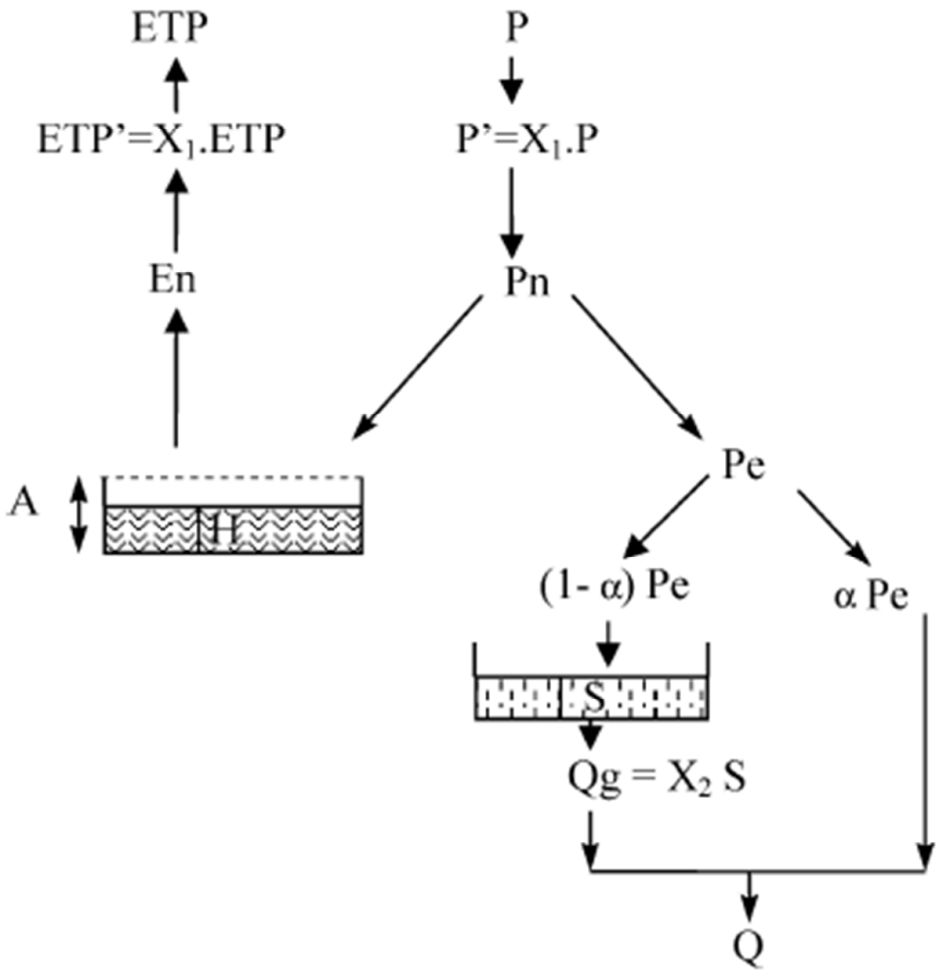

4

5

6

7

8

9

$10 \quad$ Figure 4

http://mc.manuscriptcentral.com/hyp 


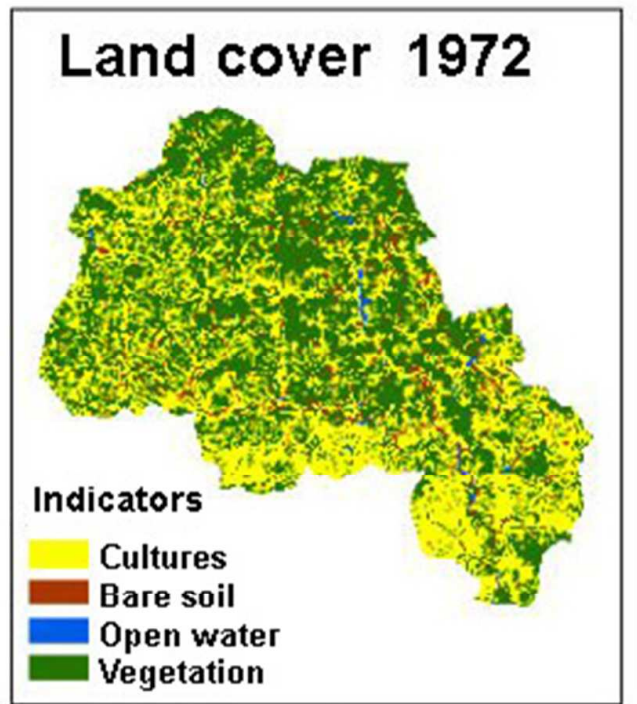

Indicators Surf. $\mathbf{k m}^{2}$ \% basin surface

\begin{tabular}{lrr}
\hline Vegetation & 10475 & 52.0 \\
Cultures & 8714 & 43.2 \\
Bare soil & 906 & 4.5 \\
Open water & 65 & 0.3
\end{tabular}

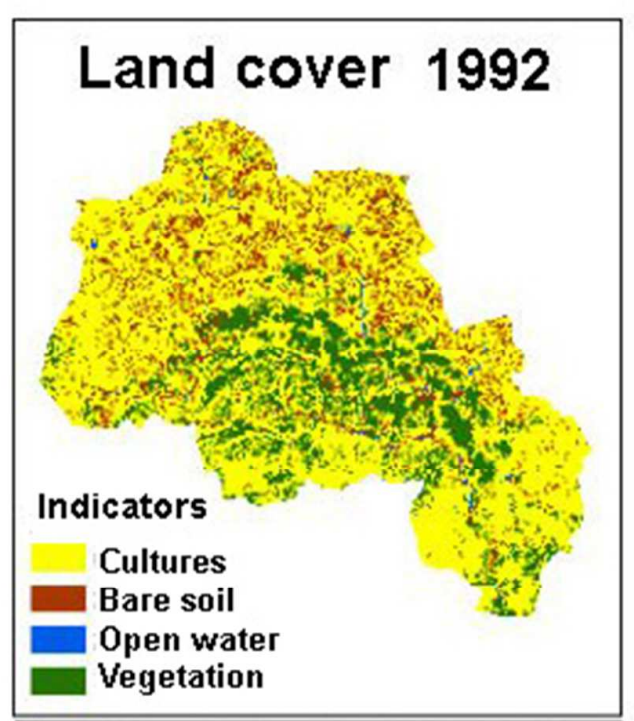

Indicators Surf. $\mathbf{k m}^{2}$ \% basin surface

\begin{tabular}{lrr}
\hline Vegetation & 3485 & 17.3 \\
Cultures & 13740 & 68.2 \\
Bare soil & 2694 & 13.4 \\
Open water & 240 & 1.2
\end{tabular}
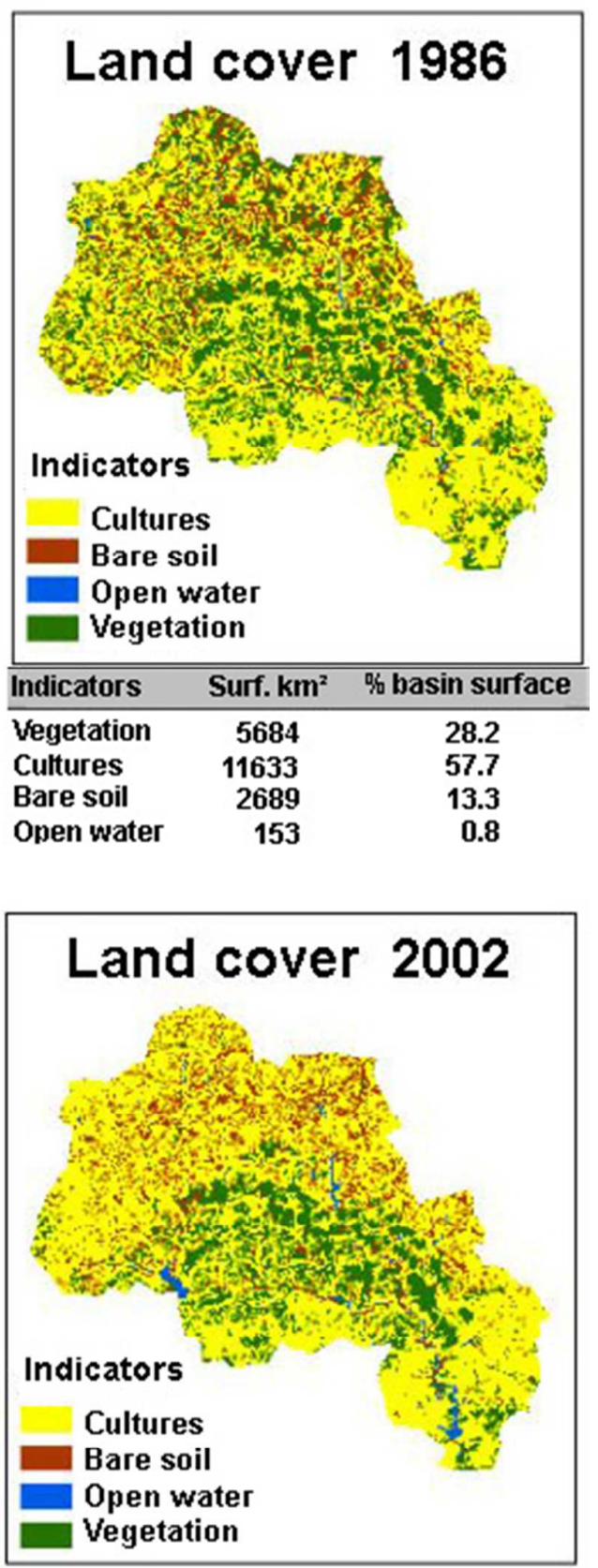

\begin{tabular}{lrc}
\hline Indicators & Surf. $\mathbf{~ k m}^{2}$ & \% basin surface \\
\hline Vegetation & 3439 & 17.1 \\
Cultures & 13624 & 67.6 \\
Bare soil & 2797 & 13.9 \\
Open water & 298 & 1.5
\end{tabular}


1

2

3

4

5

6

7

8

9

10

11

12

13

14

15

16

17

18

19

20

21

22

23

24

25

26

27

28

29

30

31

32

33

34

35

36

37

38

39

40

41

42

43

44

45

46

47

48

49

50

51

52

53

54

55

56

57

58

59

60

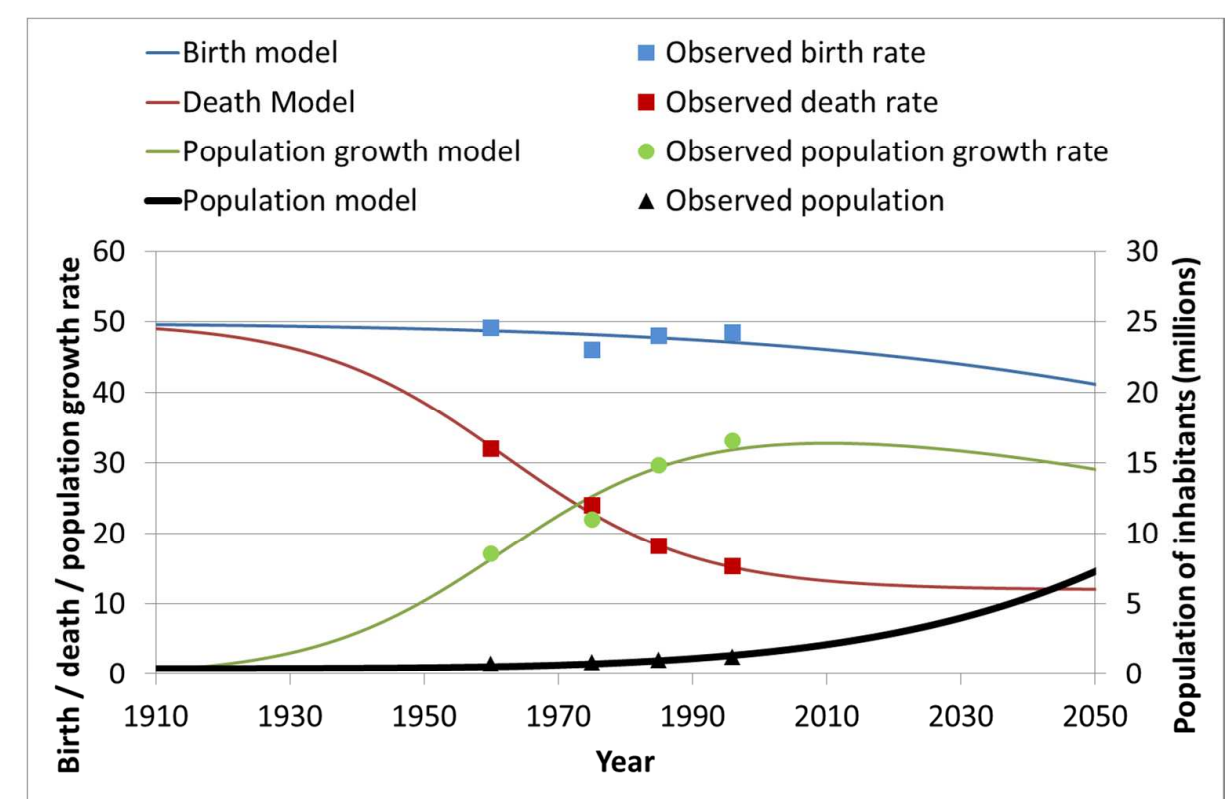

2

3

4

5

6

7

8

9

10

11

12

13 Figure 6

14

15

16

17

http://mc.manuscriptcentral.com/hyp 


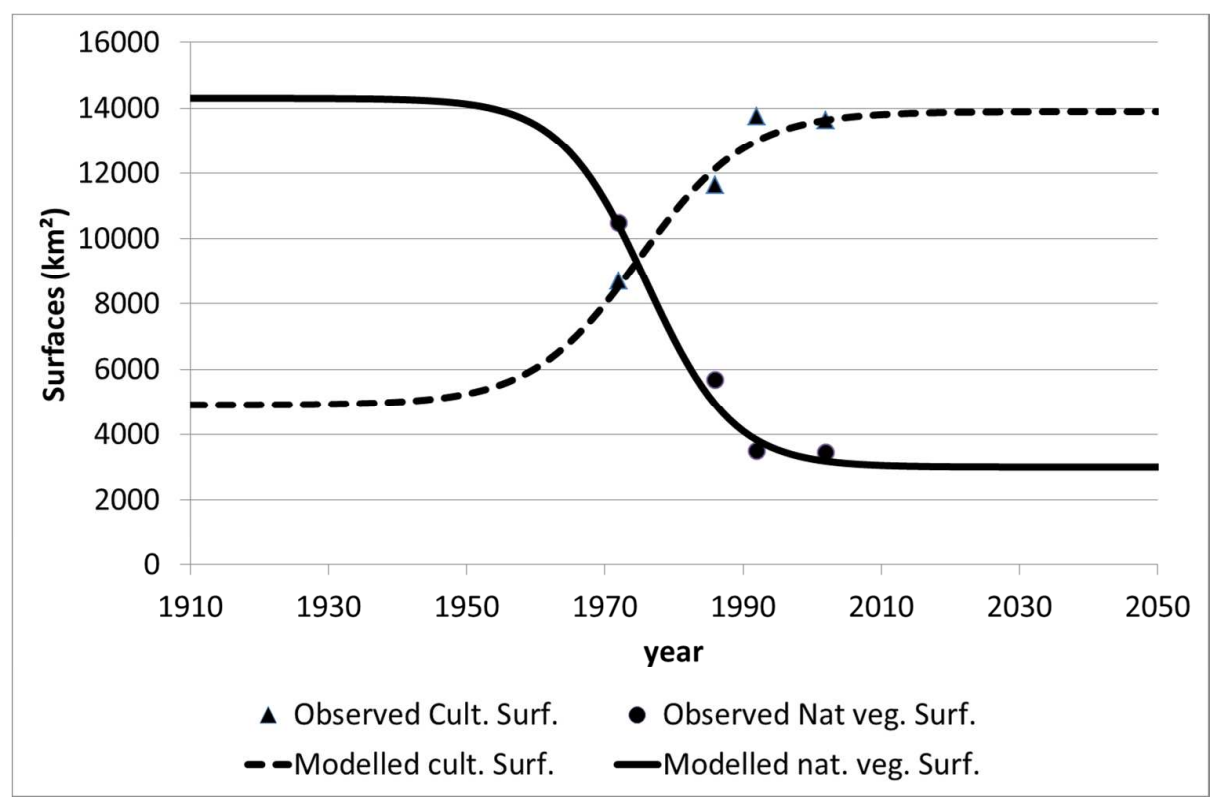

1

3

4

5

6

7

8

9

10

$11 \quad$ Figure 7

http://mc.manuscriptcentral.com/hyp 
1

2

3

4

5

6

7

8

9

10

11

12

13

14

15

16

17

18

19

20

21

22

23

24

25

26

27

28

29

30

31

32

33

34

35

36

37

38

39

40

41

42

43

44

45

46

47

48

49

50

51

52

53

54

55

56

57

58

59

60

\section{1}

2

3

4

5

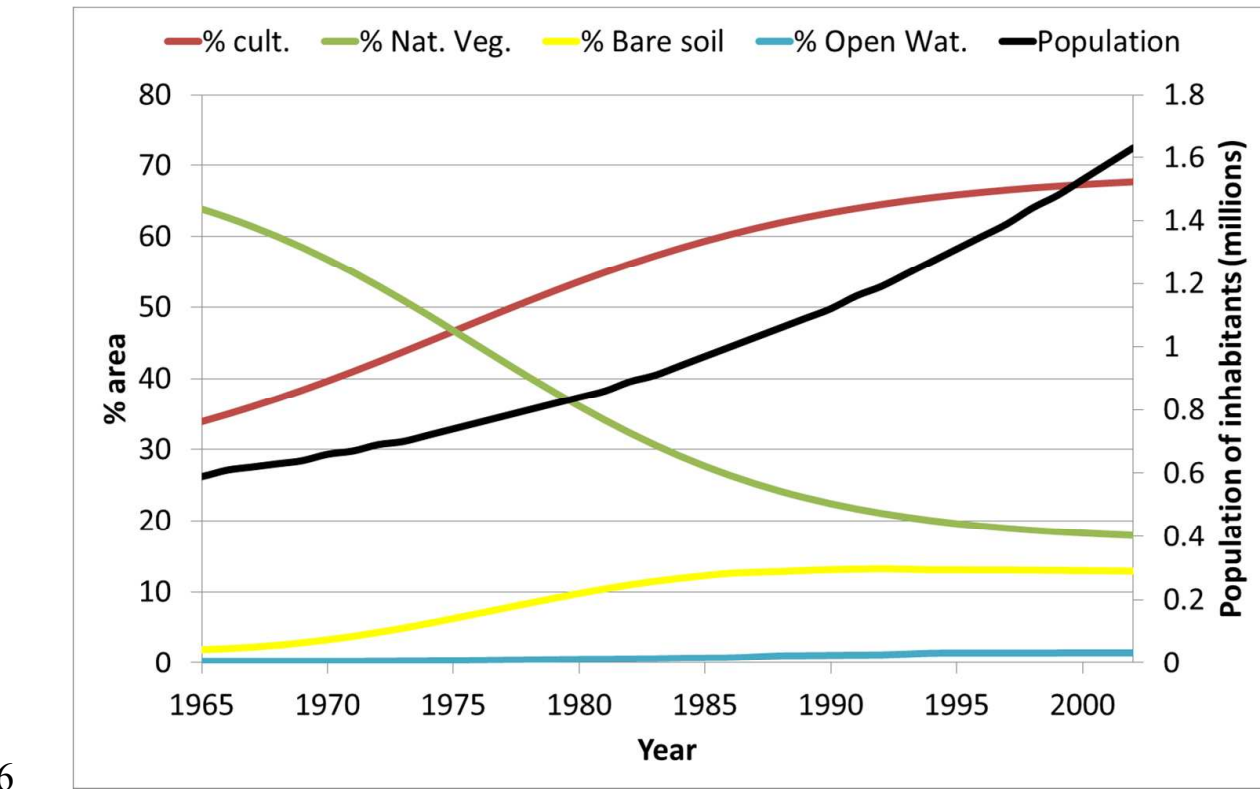

10

11

12

13

14

15

16 Figure 8

17

18

19

http://mc.manuscriptcentral.com/hyp 
1

2

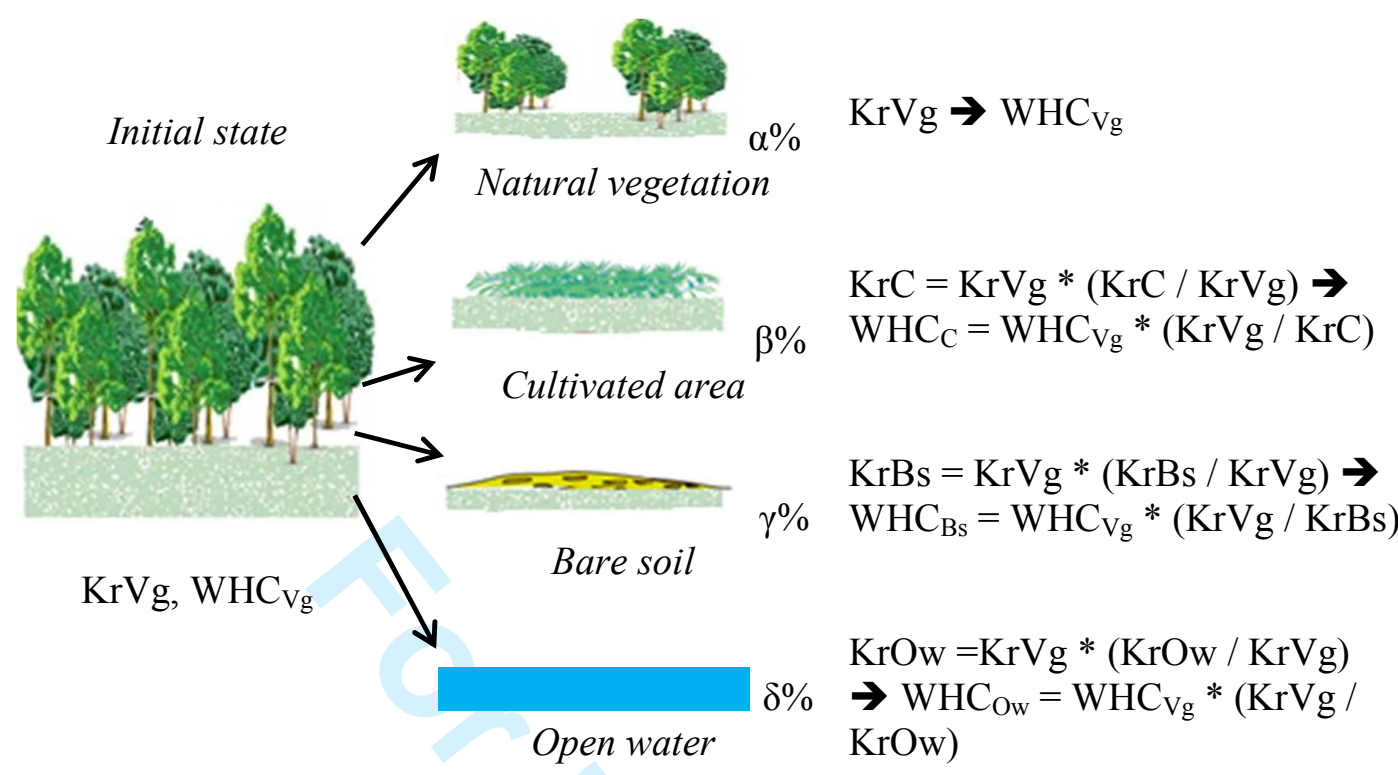

3

4

5

6

7

8

9 Figure 9

42

43

44

45

46

47

48

49

50

51

52

53

54

55

56

57

58

59

60

http://mc.manuscriptcentral.com/hyp 
1

2

3

4

5

6

7

8

9

10

11

12

13

14

15

16

17

18

19

20

21

22

23

24

25

26

27

28

29

30

31

32

33

34

35

36

37

38

39

40

41

42

43

44

45

46

47

48

49

50

51

52

53

54

55

56

57

58

59

60

\section{1}

2

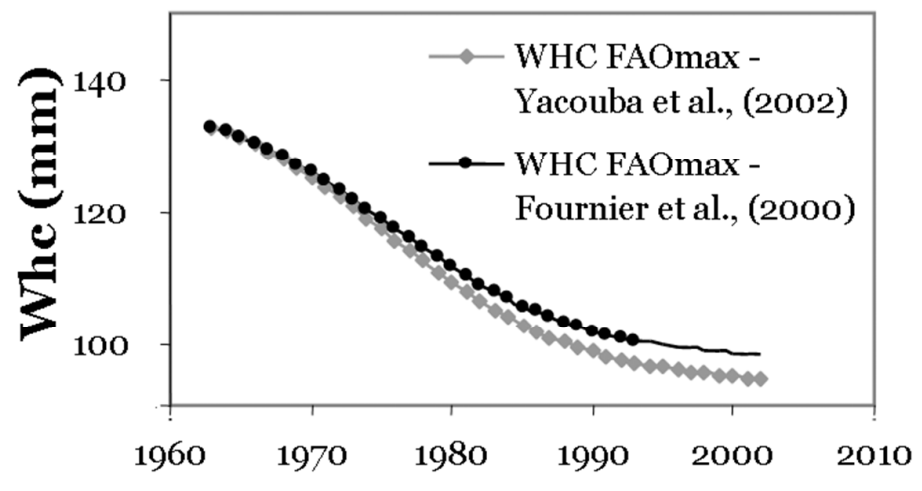

4

5

6

7

8 Figure 10 
1

2

3

4

5

6

7

8

9

10

11

12

13

14

15

16

17

18

19

20

21

22

23

24

25

26

27

28

29

30

31

32

33

34

35

36

37

38

39

40

41

42

43

44

45

46

47

48

49

50

51

52

53

54

55

56

57

58

59

60
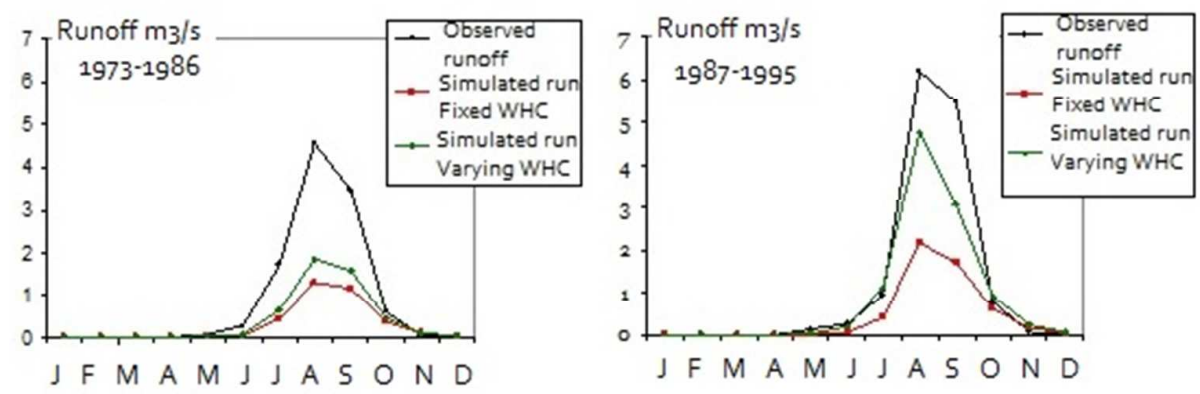

1

2

3

4

5

6

7

8

9

10

$11 \quad$ Figure 11 


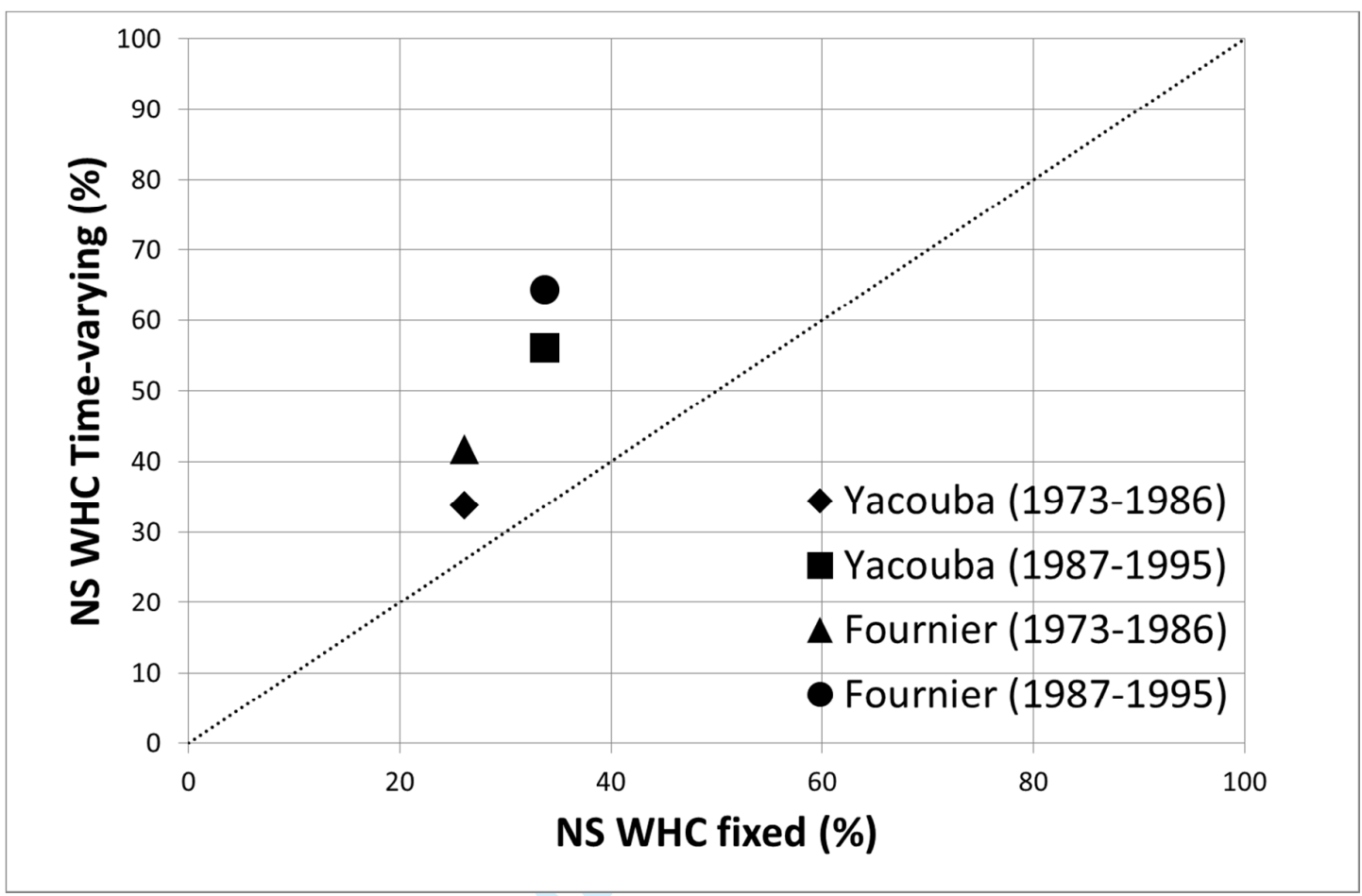

3

4

5

6

7

8

$9 \quad$ Figure 12 


\section{$1 \quad$ List of Table}

2 Table 1: Hydroclimatic characteristics of the Nakanbé basin

3 Table 2: Soils classification according to the soil water holding capacity per half-degree

4 squares (about $\left.2500 \mathrm{~km}^{2}\right)($ after FAO-UNESCO, 1974-1981) $-\mathrm{NC}=$ Non Calculated

5 Table 3: Nakanbé at Wayen - performance in terms of Nash-Sutcliffe criteria of GR2M for

6 various calibration and validation periods

7 Table 4: Nakanbé at Wayen - synthesis of the optimized WHC to maximize the values of

8 Nash-Sutcliffe criteria (\%) (according to different calibration periods); $\mathrm{NS}_{\mathrm{cal}}$ : NS in

9 calibration, $\mathrm{NS}_{\mathrm{val}}$ : NS in validation, $\mathrm{NS}_{\mathrm{opt}}$ : NS in validation but with the optimised WHC

$10 \quad\left(\mathrm{WHC}_{\mathrm{opt}}\right)$

11 Table 5: runoff coefficient for each class of land-cover, according to two authors, Fournier et

12 al. (2000) and Yacouba et al. (2002)

13 Table 6: Nakanbé at Wayen - results of the calibration/validation tests in terms of Nash-

14 Sutcliffe criteria (\%) for fixed and time-varying WHC (after runoff coefficients given by

15 Fournier et al. (2000) and Yacouba et al. (2002))

16 
Table 1

Table 2

\begin{tabular}{|c|c|c|c|c|c|}
\hline \multirow[b]{2}{*}{ Station } & \multirow{2}{*}{$\begin{array}{l}\text { Area } \\
\left(\mathbf{k m}^{2}\right)\end{array}$} & \multirow{2}{*}{$\begin{array}{c}\text { Observed } \\
\text { years }\end{array}$} & \multirow{2}{*}{$\begin{array}{l}\text { Missing } \\
\text { Months }\end{array}$} & \multicolumn{2}{|c|}{ Ratio after/before $1970(\%)$} \\
\hline & & & & $\begin{array}{l}\text { Annual } \\
\text { rainfall }\end{array}$ & $\begin{array}{c}\text { Annual } \\
\text { runoff } \\
\text { coefficient }\end{array}$ \\
\hline Wayen & 20000 & $\begin{array}{c}36(1965- \\
2000)\end{array}$ & 15 & -16 & +108 \\
\hline
\end{tabular}

3

4

5

6

Table 2

\begin{tabular}{|c|c|}
\hline Soil Class & Water Holding Capacity (mm) \\
\hline A & $>200$ \\
\hline B & $150-200$ \\
\hline C & $100-150$ \\
\hline D & $60-100$ \\
\hline E & $20-60$ \\
\hline F & $0-20$ \\
\hline W (Wetlands) & NC \\
\hline
\end{tabular}

7

8

9

Table 3

11

\begin{tabular}{|c|c|c|c|}
\hline Calibration period & NS (\%) & Validation period & NS (\%) \\
\hline \multirow{5}{*}{$1965-1969$} & \multirow{5}{*}{75.1} & $1970-1974$ & 40.2 \\
\hline & & $1970-1979$ & 39.2 \\
\hline & & 1970-1984 & 29.4 \\
\hline & & 1970-1989 & 30.5 \\
\hline & & 1970-1995 & 31.9 \\
\hline \multirow{4}{*}{$1965-1974$} & \multirow{4}{*}{60.6} & $1975-1979$ & 48 \\
\hline & & 1975-1984 & 36.4 \\
\hline & & $1975-1989$ & 41.9 \\
\hline & & 1975-1995 & 46.1 \\
\hline \multirow{3}{*}{$1965-1979$} & \multirow{3}{*}{50.3} & 1980-1984 & 33.7 \\
\hline & & 1980-1989 & 45.4 \\
\hline & & 1980-1995 & 49.6 \\
\hline \multirow{2}{*}{$1965-1984$} & \multirow{2}{*}{50.3} & 1985-1989 & 57.1 \\
\hline & & 1985-1995 & 59.7 \\
\hline $1965-1989$ & 56.7 & 1990-1994 & 68.3 \\
\hline
\end{tabular}


Table 4

\begin{tabular}{|c|c|c|c|c|c|c|c|c|c|}
\hline $\mathbf{X 1}$ & $\mathbf{X} 2$ & $\mathbf{A}$ & $\begin{array}{l}\mathrm{NS}_{\text {cal }} \\
(\%)\end{array}$ & $\begin{array}{l}\mathbf{N S}_{\text {val }} \\
(\%)\end{array}$ & $\mathrm{WHC}_{\text {opt }}$ & $\begin{array}{c}\mathbf{N S}_{\text {opt }} \\
(\%)\end{array}$ & $\begin{array}{l}N_{\text {val }} \\
(\%)\end{array}$ & $\mathrm{WHC}_{\text {opt }}$ & $\begin{array}{l}\mathrm{NS}_{\text {opt }} \\
(\%)\end{array}$ \\
\hline \multicolumn{4}{|c|}{ Calibration 1965-1972 } & \multicolumn{3}{|c|}{ Validation 1973-1986 } & \multicolumn{3}{|c|}{ Validation 1987-1995 } \\
\hline 0.26 & 0.90 & 133 & 61.6 & 34.8 & 60 & 53.7 & 52.4 & 70 & 70 \\
\hline \multicolumn{4}{|c|}{ Calibration 1973-1986 } & \multicolumn{3}{|c|}{ Validation 1965-1972 } & \multicolumn{3}{|c|}{ Validation 1987-1995 } \\
\hline 0.40 & 0.76 & 133 & 58.2 & -45.8 & 285 & 57.1 & 74.6 & 145 & 75.4 \\
\hline \multicolumn{4}{|c|}{ Calibration 1987-1995 } & \multicolumn{3}{|c|}{ Validation 1965-1972 } & \multicolumn{3}{|c|}{ Validation 1973-1986 } \\
\hline 0.39 & 0.76 & 133 & 75.2 & -17.4 & 265 & 57.4 & 57.7 & 120 & 58.1 \\
\hline
\end{tabular}

4

5

6

7

8

Table 5

\begin{tabular}{|c|c|c|}
\hline \multirow{2}{*}{ Land-use classes } & \multicolumn{2}{|c|}{ Runoff Coefficient (\%) } \\
\cline { 2 - 3 } & Yacouba & Fournier \\
\hline $\begin{array}{c}\text { Natural vegetation } \\
(\mathrm{KrVg})\end{array}$ & 17 & 13 \\
\hline Cultivated area $(\mathrm{KrC})$ & 24 & 20 \\
\hline Bare soil $(\mathrm{KrBs})$ & 54 & 50 \\
\hline Water body $(\mathrm{KrWb})$ & 100 & 100 \\
\hline
\end{tabular}

9

10 
Table 6

\begin{tabular}{|c|c|c|c|c|c|c|c|c|}
\hline & \multicolumn{2}{|c|}{ CALIBRATION } & \multicolumn{6}{|c|}{ VALIDATION } \\
\hline WHC & PERIOD & $\begin{array}{l}\text { NS } \\
(\%)\end{array}$ & PERIOD & $\begin{array}{l}\text { NS } \\
(\%)\end{array}$ & PERIOD & $\begin{array}{l}\text { NS } \\
(\%)\end{array}$ & PERIOD & $\begin{array}{l}\text { NS } \\
(\%)\end{array}$ \\
\hline Fixed & \multirow{3}{*}{$\begin{array}{r}1965- \\
1972\end{array}$} & 73 & \multirow{3}{*}{$\begin{array}{c}1973- \\
1986\end{array}$} & 26.2 & \multirow{3}{*}{$\begin{array}{c}1987- \\
1995\end{array}$} & 33.8 & \multirow{3}{*}{$\begin{array}{c}1973- \\
1995\end{array}$} & 31.1 \\
\hline $\begin{array}{c}\text { Time- } \\
\text { varying } \\
\text { (Yacouba) }\end{array}$ & & 72 & & 37.1 & & 56 & & 49 \\
\hline $\begin{array}{c}\text { Time- } \\
\text { varying } \\
\text { (Fournier) }\end{array}$ & & 71.5 & & 41.7 & & 64.3 & & 55.9 \\
\hline Fixed & \multirow{3}{*}{$\begin{array}{c}1973- \\
1986\end{array}$} & 63.7 & \multirow{3}{*}{$\begin{array}{l}1965- \\
1972\end{array}$} & -231.1 & \multirow{3}{*}{$\begin{array}{l}1987- \\
1995\end{array}$} & 74.2 & & \\
\hline $\begin{array}{c}\text { Time- } \\
\text { varying } \\
\text { (Yacouba) }\end{array}$ & & 67.6 & & -106.9 & & 67.9 & & \\
\hline $\begin{array}{c}\text { Time- } \\
\text { varying } \\
\text { (Fournier) }\end{array}$ & & 68.9 & & -68.6 & & 58.2 & & \\
\hline Fixed & \multirow{3}{*}{$\begin{array}{r}1987- \\
1995\end{array}$} & 75.3 & \multirow{3}{*}{$\begin{array}{c}1965- \\
1972\end{array}$} & -291.5 & \multirow{3}{*}{$\begin{array}{c}1973- \\
1986\end{array}$} & 62.8 & \multirow{3}{*}{$\begin{array}{c}1965- \\
1986\end{array}$} & 27.7 \\
\hline $\begin{array}{c}\text { Time- } \\
\text { varying } \\
\text { (Yacouba) }\end{array}$ & & 74.2 & & -8.7 & & 63.5 & & 57 \\
\hline $\begin{array}{c}\text { Time- } \\
\text { varying } \\
\text { (Fournier) }\end{array}$ & & 73.4 & & 41.2 & & 60.2 & & 59.1 \\
\hline Fixed & \multirow{3}{*}{$\begin{array}{c}1965- \\
1986\end{array}$} & 48.9 & \multirow{3}{*}{$\begin{array}{c}1987- \\
1995\end{array}$} & 61.8 & & & & \\
\hline $\begin{array}{c}\text { Time- } \\
\text { varying } \\
\text { (Yacouba) }\end{array}$ & & 57.1 & & 72.6 & & & & \\
\hline $\begin{array}{c}\text { Time- } \\
\text { varying } \\
\text { (Fournier) }\end{array}$ & & 60 & & 70.7 & & & & \\
\hline
\end{tabular}

